\title{
FACTORS IN GEOTROPOSPHERIC PARTICLE-GAS TRANSPORT OF SEMIVOLATILE ORGANIC COMPOUNDS
}

\author{
Daniel A. Vallero ${ }^{1 \dagger}$ \\ ${ }^{1}$ National Exposure Research Laboratory, U.S. Environmental Protection Agency, \\ Research Triangle Park, NC 27711, U.S.A
}

Submitted to

Environmental Engineering Science

May 1, 2004

${ }^{\dagger}$ Corresponding author: National Exposure Research Laboratory, U.S.

Environmental Protection Agency, Research Triangle Park, NC 27711, U.S.A; Phone. (919) 530-7609 E-mail: dvallero@wpo.nccu.edu 
Factors in Geotropospheric Particle-Gas Transport of Semivolatile Organic Compounds

\author{
Daniel A. Vallero ${ }^{1 \dagger}$ \\ ${ }^{1}$ National Exposure Research Laboratory, U.S. Environmental Protection Agency, \\ Research Triangle Park, NC 27711, U.S.A
}

\begin{abstract}
Semivolatile organic compounds (SVOCs) can exist in solid, liquid, or gas phases under ambient environmental conditions. The geotropospheric transport of SVOCs varies according to the particle type. Two classes of SVOCs and two types of particles were analyzed to determine possible transport mechanisms to the troposphere: dicarboximide compounds moving from a soil matrix to the troposphere and polycyclic aromatic hydrocarbons (PAHs) from airborne particles to the troposphere . Both classes of compounds are considered to be SVOCs since their vapor pressures under most environmental conditions range between $10^{-2}$ to $10^{-5} \mathrm{kP}$. The dicarboximide results were obtained from a laboratory chamber designed and used to determine the headspace flux of the dicarboximide fungicide, vinclozolin (3-(3,5-dichlorophenyl)-5-methyl-5-vinyloxzoli-dine-2,4-dione), and its three principal degradation products from chamber

\footnotetext{
${ }^{\dagger}$ National Exposure Research Laboratory, U.S. Environmental Protection Agency, Research Triangle Park, NC 27711, U.S.A; Phone. (919) 541-3306 E-mail: vallero.daniel@epa.gov
} 
surfaces, sand, and sterilized and non-sterile North Carolina Piedmont aquic hapludult soils following dicarboximide applications. The PAH results were gathered from a highvolume air sampling system used to measure particle and gas phase concentrations of SVOCs in the plume downwind from the World Trade Center fire. The comparison indicates that SVOC transport from the soil matrix can be influenced by the type and size of particles, their chemical composition, $\mathrm{pH}$, oxygen, and microbial action. The study indicates that in the troposphere, molecular weight and structure are the principal factors affecting the geotropospheric flux of SVOCs from the particle to gas phase. Although experimentally determined equilibrium constants are more robust predictors of phase distribution in the troposphere $\left(r^{2}=0.81\right)$, published Henry's Law and vapor pressure constants also relate to particle-gas phase distribution $\left(r^{2}=0.73\right.$ and 0.72 , respectively).

Key words: Particle, aerosol, semivolatile organic compound, soil matrix, polycyclic aromatic hydrocarbons, dicarboximides, tropospheric flux, phase distribution, Henry's Law constant, particle-gas partitioning coefficient. 


\section{INTRODUCTION}

The chemical class of compounds known as semivolatile organic compounds (SVOCs) comprises some of the most toxic, bioaccumulating, and persistent environmental contaminants. The SVOCs have vapor pressures between $10^{-5}$ and $10^{-2}$ kilopascals. These values correspond to classifications that are based upon observations of the compounds' behaviors during air sampling (Lewis and Gordon 1996). A particularly important aspect of SVOCs is that they may be transported from soil in the gas phase or as aerosols (Williams et al. 1999).

Many products of incomplete combustion, such as polycyclic aromatic hydrocarbons, dioxins, furans, and hexachlorobenzene, as well as numerous pesticides, phenolics, solvents, and pharmaceuticals are members of the SVOC chemical classification. An understanding of the factors that lead to the release, movement, and degradation of semivolatile organic compounds provides information on how to abate the atmospheric transport of contaminants in order to reduce or prevent human and environmental exposures.

This study considers the flux of two classes of SVOCs, dicarboximides and polycyclic aromatic hydrocarbons (PAHs). The structures are shown in Figure 1. Like the dicarboximides, PAHs may exist in either the particle or gas phase under environmental conditions. Dicarboximides are intentionally applied pesticides. PAHs are unintentional products of incomplete combustion.

After the collapse of the World Trade Center (WTC) towers in lower Manhattan, New York City, aerosols were emitted from ground level and moving downwind. For the 
first 12 to 18 hours after the collapse, the winds transported the plume to the east and then to the southeast toward Brooklyn, NY. Particles not only included those released from the fire that burned for many weeks, but also those that became re-suspended by air turbulence and mechanical disturbance. Some contaminants that were found in the measurements at WTC have been associated with human health effects that include carcinogenic compounds (e.g. benzo(a)pyrene and other PAHs) from smoldering fires, endocrine disruptors (e.g. phthalates and styrene derivatives from plastics), and neurotoxins (such as dioxins from incomplete combustion).

The author participated in two recent studies concerned with the transport of SVOCs from a soil matrix (Vallero and Peirce, 2002) and the distribution of SVOCs between gas and particulate phases (Swartz, et al., 2003). The present study analyzes the data from these two investigations to identify factors that affect the flux in the soil and air compartments. By comparing the flux of dicarboximide from soil in a chamber to field measurements of PAHs, it is possible to identify similarities and differences in the geotropospheric phase distribution from soil matrices and from airborne particles. This has helped to characterize particle behavior in two important environmental compartments, soil and air.

\section{MATERIALS AND METHODS}

\section{Sampling Methods for Dicarboximides}

The $36 \mathrm{~cm}$ height $\times 10 \mathrm{~cm}$ interior diameter SVOC chamber (Figure 2) includes a soil mixing system, a headspace stirrer and an air sampling system (PUF trap). The test 
system consists of non-reactive stainless steel, Teflon, and glass. The fungicide suspension was sprayed onto the top surface of the soil column. A $15 \mathrm{~cm}$ soil column simulated the depth of the plow layer of O (organic) and A (topsoil) horizons. The headspace was completely mixed by the air stirrer at $0.1 \mathrm{~L} \min ^{-1}$ airflow. A $15 \mathrm{~cm}$ soil column in the chamber provides $800 \mathrm{~mL}$ soil volume. A soil matrix was of two major types, i.e. sand and soil. The sand matrix consisted of a 20-30mesh Ottawa laboratorygrade sand $\left(99.7 \%\right.$ silica) contained $<1 \%$ moisture, with a bulk density of $1.73 \mathrm{~g} / \mathrm{cm}^{3}$, with 35\% porosity. The soil matrix was a North Carolina aquic hapludult soil drawn from the top $10 \mathrm{~cm}$ of an A-horizon plow layer located within a $2 \mathrm{~m}^{2}$ plot of fallow farmland. The soil was sized through a \#10 Tyler equivalent stainless steel sieve. Prepared soils were homogenized and air-dried for $24 \mathrm{~h}$ at $20^{\circ} \mathrm{C}$ at $<30 \% \mathrm{RH}$ in a humidity-controlled room. The bulk density of the soil was found to be $1.27 \mathrm{~g} / \mathrm{cm}^{3}$, with $48 \%$ porosity.

Following each experiment the soil or sand was removed and thoroughly mixed by shaking on a shaker table for $10 \mathrm{~min}$ and turning the sample bag over 20 times. Five $2 \mathrm{~g}$ samples were then taken from each experiment's soil, placed in 3mL acetonitrile, and ultrasonically extracted for 30min, along with a $2 \mathrm{~g}$ soil blank and a $2 \mathrm{~g}$ soil sample spiked with a known amount of vinclozolin. The extracts were analyzed by HPLC-UV.

The flux of dicarboximides moving from the soil to the chamber headspace was measured under conditions of low and high soil $\mathrm{pH}$ values, low and high precipitation events, and surface application and soil incorporation of the fungicide. The fungicide label instructions (BASF Corporation 1997) allow for a seasonal total of $13.5 \mathrm{~kg} \mathrm{ha}^{-1}$ application rate, equivalent to $5 \mathrm{~mL}$ of a $2200 \mathrm{mg} \mathrm{L}^{-1}$ fungicide/de-ionized water suspension was sprayed onto the $78.5 \mathrm{~cm}^{2}$ soil surface in the chamber. The hydrophobic 
vinclozolin (i.e., $3.5 \mathrm{mg} \mathrm{L}^{-1}$ solubility in water) was kept in suspension by ultrasonic treatment in de-ionized water for 15min prior to spraying. Even with mixing, however, chemical analysis indicated that the percentage of inert ingredients and vinclozolin varied, with the mean mass of vinclozolin in the soil ranging between $4.4 \mathrm{mg}$ to $6.4 \mathrm{mg}$ in individual experiments.

Experiments were conducted with a non-sterile and sterilized North Carolina Piedmont aquic hapludult soil or 20-30 mesh Ottawa sand. All experiments were conducted in duplicate; i.e., $\mathrm{n}=2$. In the soil experiments, approximately $800 \mathrm{~mL}$ of nonsterile North Carolina Piedmont hapludult soil (1 kg) received the fungicide/fluid suspension. In the sand experiments, the $800 \mathrm{~mL}$ of sand weighed approximately $1.3 \mathrm{~kg}$. Target soil moistures were set at $10 \%$ and $20 \%$ fluid-filled pore space (FFPS) in the $15 \mathrm{~cm}$ chamber soil column, respectively, if the moisture were uniformly distributed throughout the soil column. Target fluid $\mathrm{pH}$ was achieved and maintained by applying buffer solutions- $-\mathrm{pH}$ 4.6, 0.1M sodium acetate-acetic acid and $\mathrm{pH}$ 9.0, 0.1M boric acidpotassium chloride-sodium hydroxide - as "rain events" directly to the surface of the matrix. Using standard methods (McLean, 1982), the pH 4.6 buffer acidified the sand to $\mathrm{pH} 4.6$ and the soil to $\mathrm{pH} 4.7$, while the $\mathrm{pH} 9.0$ buffer was found to increase the $\mathrm{pH}$ of the sand to 8.8 and the $\mathrm{pH}$ of the soil to 7.8 . These $\mathrm{pH}$ values were achieved within $15 \mathrm{~min}$ and remained within \pm 0.3 for the duration of the experiments.

Only about $25 \%$ of the soil column received added moisture from surface applications alone. In the incorporation experiments, the fungicide was mixed into the soil using the harrow disc system in the chamber. Complete incorporation was achieved 
with 100 turns of the harrow disc crank (see Figure 2). The entire set-up time of spraying, infiltration of the buffer solution into the soil and harrowing took approximately $10 \mathrm{~min}$.

The mass balance is expressed as a function of advection, dispersion and reaction (Vallero and Peirce, 2001; Hemond and Fechner, 1996):

$$
\frac{\mathrm{d}[\mathrm{C}]^{\mathrm{SVOC}}}{\mathrm{dt}}=\left[\frac{\mathrm{Q}[\mathrm{C}]_{0}^{\mathrm{SVOC}}}{\mathrm{V}_{\mathrm{A}}}+\frac{\mathrm{J}^{\mathrm{SVOC}} \mathrm{A}}{\mathrm{V}_{\mathrm{A}}}\right]-\left[\frac{\Psi^{\mathrm{SVOC}} \mathrm{A}^{\prime}}{\mathrm{V}_{\mathrm{A}}}+\frac{\mathrm{Q}[\mathrm{C}]_{\mathrm{f}}^{\mathrm{SVOC}}}{\mathrm{V}_{\mathrm{A}}}\right]+\mathrm{R}_{\mathrm{A}}-\mathrm{D}_{\mathrm{A}}
$$

where:

$$
\begin{aligned}
& {[\mathrm{C}]^{\mathrm{SVOC}}=\text { SVOC concentration in the chamber }\left(\mu \mathrm{g} \mathrm{L}^{-1}\right)} \\
& {[\mathrm{C}]_{0}^{\mathrm{SVOC}}=\text { SVOC concentration at the inlet of the chamber }\left(\mu \mathrm{g} \mathrm{L}^{-1}\right)} \\
& {[\mathrm{C}]_{\mathrm{f}}^{\mathrm{SVOC}}=\text { SVOC concentration at the outlet of the chamber }\left(\mu \mathrm{g} \mathrm{L}^{-1}\right)} \\
& \mathrm{J}^{\mathrm{SVOC}}=\quad \text { SVOC emission from the soil, flux per unit area }\left(\mu \mathrm{g} \mathrm{cm}^{-2} \mathrm{~s}^{-1}\right) \\
& A=\quad \text { Soil-air interface }\left(\mathrm{cm}^{2}\right) \\
& \mathrm{V}_{\mathrm{A}}=\quad \text { Headspace volume (L) } \\
& \Psi^{\text {SVOC }}=\text { SVOC deposition of SVOC to } A_{A}^{\prime}\left(\mu \mathrm{g} \mathrm{cm}^{-2} \mathrm{~s}^{-1}\right) \\
& \mathrm{A}^{\prime}=\quad \text { chamber surfaces in contact with headspace, except } \mathrm{A}\left(\mathrm{cm}^{2}\right) \\
& \mathrm{Q}=\quad \text { zero grade airflow }\left(\mathrm{L} \mathrm{s}^{-1}\right) \\
& \mathrm{R}_{\mathrm{A}}=\quad \text { chemical production rate for SVOC in headspace }\left(\mu \mathrm{g} \mathrm{L}^{-1} \mathrm{~s}^{-1}\right) \\
& \mathrm{D}_{\mathrm{A}}=\quad \text { chemical destruction rate for SVOC in headspace }\left(\mu \mathrm{L} \mathrm{L}^{-1} \mathrm{~s}^{-1}\right)
\end{aligned}
$$


Since the four dicarboximides were below detection limits in all blanks, $[\mathrm{C}]_{0}^{\mathrm{SVOC}}$ was assumed to be zero. The production $\mathrm{R}$ and destruction $\mathrm{D}$ terms were also set at zero, since the actual amount of degradation was represented by actual measurements of the four compounds. Thus, soil-to-air flux can be simplified:

$$
\mathrm{J} \mathrm{h}^{-1}=\left(\mathrm{QV}{ }^{-1}+\Psi \mathrm{h}^{-1}\right)[\mathrm{C}]^{\mathrm{SVOC}}
$$

where:

$\mathrm{h}=$ Chamber headspace height $(\mathrm{cm})$.

The flux $\mathrm{J}$ was determined from the concentration of each of the four compounds found on the PUF samples (i.e., $[\mathrm{C}]^{\mathrm{SVOC}}$ ), which was integrated over the intervals of 10 minutes to 5 hours, 5 hours to 10 hours, and 10 hours to 1 day following the spray event, at a constant flow (Q) of $0.1 \mathrm{~L} \mathrm{~min}$ ming $^{-1}$ during the experiments. The $\Psi^{\mathrm{SVOC}}$ values were obtained by wiping all A' surfaces with acetonitrile-soaked paper wipes, and ultrasonically extracting the wipes in acetonitrile. The total mass of dicarboximides on $\mathrm{A}^{\prime}$ surfaces ranged from 4 to $94 \mu \mathrm{g}$, so the derived $\Psi^{\text {svoc }}$ values ranged from 23 to $531 \mathrm{ng}$ $\mathrm{m}^{-2} \mathrm{hr}^{-1}$, possibly indicating the compounds' affinity for glass and Teflon surfaces. However, since most of the mass was vinclozolin, it could also indicate that the pesticide may have aerosolized during the spray event and was immediately deposited onto the surfaces. 
Chamber experiments were conducted in empty chambers, in dry sand, in ovendried, sterile sand with $10 \%$ and $20 \%$ moisture. To determine the role of microbial mediation on flux in non-sterile and sterilized (i.e. autoclaved for one hour for three consecutive days as recommended by Alphei and Scheu 1993) soils, North Carolina Piedmont aquic hapludult soil received the fungicide spray with $0.1 \mathrm{M} \mathrm{pH9.0} \mathrm{and} \mathrm{with}$ 0.1M pH4.6 buffer solution added (to differentiate $\mathrm{pH}$ effects). All air flux samples were collected on $22 \mathrm{~mm}$ diameter $\times 38 \mathrm{~mm}$ length, $0.022 \mathrm{~g} / \mathrm{cm}^{3}$ PUF plugs (Supelco, Inc., L214, lot 6217), pre-cleaned to <100ng total contaminants.

\section{Sampling Methods for Polycyclic Aromatic Hydrocarbons}

A high capacity Integrated Organic Gas and Particle (HiC IOGAP) (URG model 3000DB) sampler with a $2.5 \mu \mathrm{m}$ cyclone inlet for particle discrimination was used to collect semi-volatile gases and particles for speciation of organic compounds (Figure 3). A pre-baked quartz filter followed by three XAD-4 impregnated quartz filters is used to collect the particle phase. The XAD-4 impregnated quartz filters are used to collect those compounds that desorb from the particles on the quartz filters and/or not removed by the denuders. Another configuration was run with a $2.5 \mu \mathrm{m}$ cyclone, a quartz filter, and three XAD-4 impregnated quartz filters. This scheme is typically associated with conventional filter-based measurements: a quartz filter and a back-up sorbant substrate (in this case three XAD-4 impregnated quartz filters). In this configuration both the particle and gas phase species are collected on the filters. 
The HiC IOGAP sampler was operated about 500 meters from the World Trade Center on an offset on the $16^{\text {th }}$ floor (about 50 meters) of the EPA Federal Building at 290 Broadway, New York, NY (see Figure 4, map of the sampling site relative to the WTC). The flow rate of the HiC IOGAP sampler was $85 \mathrm{~L} \mathrm{~min}^{-1}$ and temperature controlled at $4^{\circ} \mathrm{C}$ above ambient to prevent condensation of water. The sampling time was either 11.5 hours day $^{-1}$ or 23 hours day $^{-1}$ between $9 / 26 / 01$ 10/21/01. The sample collected on September 26, 2001 was chosen because it was the first sample collected after 9/11. The wind direction on this day was from the westsouthwest. The samples collected on 10/4, 10/12, and 10/20 were chosen to characterize the semi-volatile concentrations due to their relatively high mass loading, and since the wind direction was from the southwest, directly impacting the sampling site. On October 6, 2001 a low pressure system came into the region, precipitation was intermittent in the morning (7:00am and 10:00am) and the prevailing wind direction was out of the north. This sample was ideally chosen to characterize the background semi-volatile concentrations during this time. Each sample set consisted of either two annular denuders, one quartz filter and three XAD-4 impregnated quartz filter, or with a single quartz filter and three XAD-4 impregnated quartz filters. The denuders (sealed with Teflon caps) and filters (in Teflon-sealed $50 \mathrm{~mL}$, pre-baked at $500^{\circ} \mathrm{C}$, glass centrifuge tubes) were stored at room temperature.

Before extraction from the field, each denuder was coated with fine particles of XAD-4 (Gundal, 1998; Gundal, et al., 2001; Gundal, et al., 1998), and spiked with $0.1 \mathrm{~mL}$ of a deuterated hydrocarbon mixture as field surrogates to monitor processing losses during 
sample extraction and preparation. The surrogate recovery was evaluated for acceptance by determining whether the measured concentration fell within the acceptance limits of 80-120 percent. The deuterated hydrocarbon solution contained $\mathrm{nC}_{16} \mathrm{D}_{34}\left(6.0 \mu \mathrm{g} \mathrm{mL}{ }^{-1}\right)$ anthracene- $\mathrm{d}_{10}\left(2.7 \mu \mathrm{g} \mathrm{mL}^{-1}\right)$, and chrysene- $\mathrm{d}_{10}\left(0.5 \mu \mathrm{g} \mathrm{mL} \mathrm{L}^{-1}\right)$, all in hexane, at concentrations estimated to be similar to the native airborne PAH.

The denuders and filters were extracted in a solvent mixture of equal volumes of pesticide grade hexane, dichloromethane and methanol (Hex:MeCl $2: \mathrm{MeOH})$ at EPA's National Exposure Research Laboratory in RTP, NC. Each denuder was extracted twice using a "rolling rinse" method (Swartz, et al., 2003), where the capped denuder was rolled back and forth on a smooth surface for 30 revolutions. Compared to previous inversion methods, the rolling rinse provides greater solvent contact with the absorbent coating in the denuder. The second extract serving as the denuder blank for the next use of that denuder. Swartz, et al. (2003) found that $>85 \%$ of the analytes were removed between first and second extraction. Quartz filters and XAD-4 impregnated quartz filters were each extracted twice by sonication for 1 hour at $55^{\circ} \mathrm{C}$ in $50 \mathrm{~mL}$ of Hex: $\mathrm{MeCl}_{2}: \mathrm{MeOH}$ solvent and filtered by the same procedure as used for denuder extracts. Separate quartz and XAD-4 impregnated filters were used as field blanks. Surrogate recovery was evaluated for acceptance by determining whether the measured concentration fell within the acceptance limits of 80-120 percent.

\section{Analytical Methods for Dicarboximides}


Analysis of vinclozolin and its three degradation products was conducted by high performance liquid chromatography (HPLC) using a Hewlett Packard ${ }^{\circledR}$ Model 1100 HPLC system with a Alltech ${ }^{\circledR} \mathrm{C}_{18}$ stationary phase column and a gradient program for methanol, acetonitrile, and $0.05 \mathrm{M}, \mathrm{pH} 3.3$ phosphate buffer in the mobile phase. The buffer was prepared from 6g sodium phosphate-monobasic (Aldrich, no purity reported) dissolved in 1L de-ionized water and phosphoric acid. On-column injection volumes were $50 \mu \mathrm{L}$ acetonitrile solutions. The mobile phase flow rate was $1 \mathrm{~mL} \mathrm{~min}{ }^{-1}$. A Hewlett Packard $^{\circledR}$ ultraviolet/diode array detector isolated the spectra for UV absorption. The wavelengths selected from the array were $212 \mathrm{~nm}$ and $219 \mathrm{~nm}$, with reported values quantitated from $219 \mathrm{~nm}$ peaks. Fluorescence was used to help to identify extraneous peaks at or near the retention times of the dicarboximides, since vinclozolin and the three degradates do not fluoresce. The pump pressure reached a maximum of 142 bar to maintain 290 bar column pressure. The two intermediate degradation products of vinclozolin, i.e. 2-[(3,5-dichlorophenyl)-carbamoyl]oxy-2-methyl-3-butenoic acid (“M1butenoic acid”) and 3',5'-dichloro-2-hydroxy-2-methylbut-3-enanilide (“M2-enanalide”), were hydrolyzed from vinclozolin (Supelco, 99.6\%+\%). Standard solutions of vinclozolin, M1-buteonic acid, M2-enanalide, and DCA were prepared in acetonitrile. Acetonitrile blanks were analyzed at the beginning and end of each run to determine whether drift or cross-contamination of samples occurred. Limits of detection in acetonitrile were $7 \mathrm{ng} \mathrm{L}^{-1}$ vinclozolin, $10 \mathrm{ng} \mathrm{L}^{-1} \mathrm{M} 1,6 \mathrm{ng} \mathrm{L}^{-1} \mathrm{M} 2$, and $1 \mathrm{ng} \mathrm{\textrm {L } ^ { - 1 }}$ DCA. The limits of detection for flux derived from these values were $500 \mathrm{pg} \mathrm{m}^{-2} \mathrm{~h}^{-1}$ vinclozolin, 800 pg $\mathrm{m}^{-2} \mathrm{~h}^{-1} \mathrm{M} 1,500 \mathrm{pg} \mathrm{m}^{-2} \mathrm{~h}^{-1} \mathrm{M} 2$, and $80 \mathrm{pg} \mathrm{m}^{-2} \mathrm{~h}^{-1}$ DCA. 
Supercritical fluid extraction using active trap collection and solvent modification (Suprex Autoprep $44^{\circledR}$ ) was used to extract all residues from PUF. All other materials were extracted ultrasonically in acetonitrile. The amount of extraction time needed was determined experimentally by dosing the material and finding the amount of time when $100 \%$ extraction occurred, or when extraction efficiency had become stable.

\section{Analytical Methods for Polycyclic Aromatic Hydrocarbons}

Analysis of the extracts was performed using a Varian Saturn $\mathrm{IV}^{\circledR}$ Gas Chromatography- ion trap Mass Spectrometer (GC-MS) with a SPI injection system. The gas chromatograph used a 30-meter Rtx-5Sil MS column (0.28 mm ID, $0.25 \mu \mathrm{m}$ film thickness) and a 10-meter Integra Guard column. The carrier gas was helium at a flow rate of $1 \mathrm{~mL} \mathrm{~min}^{-1}$. The oven temperature was held at $60^{\circ} \mathrm{C}$ for 5 minutes, heated at $10^{\circ} \mathrm{C} \min ^{-1}$ to $140^{\circ} \mathrm{C}$, heated at $5^{\circ} \mathrm{C} \min ^{-1}$ to $320^{\circ} \mathrm{C}$, and held at $320^{\circ} \mathrm{C}$ for 15 minutes. The mass spectrometer was operated under the following conditions: trap temperature of $225^{\circ} \mathrm{C}$, emission current of $15 \mu \mathrm{A}$, scan rate of 50-350 Daltons in 0.5 seconds and A/M amplitude was 3.0 Volts. The organic compounds were identified by comparison with retention times and mass spectra of authentic standards if available or referenced to the NIST98 and Wiley mass spectra libraries. The standard deviation for repetitive GC-MS runs was $<4 \%$.

The importance of airborne particles led to the taking of many measurements around "Ground Zero," but the chemical composition of these particles can be very 
complex. Analyses at WTC by Lioy, et al (2002) showed the particulate matter in settled dust contained pulverized building material, rendering it basic $(\mathrm{pH}>9)$ and alkaline as a result of significant fractions of inorganic matter and metals (e.g. $>35 \mu \mathrm{g} \mathrm{g}^{-1}$ calcium, > $110 \mu \mathrm{g} \mathrm{g}^{-1}$ magnesium, $>1500 \mu \mathrm{g} \mathrm{g}^{-1}$ titanium, and $>500 \mu \mathrm{g} \mathrm{g}^{-1}$ aluminum). The cement/carbon ratio ranged between 37 and 50\%, and the glass fiber content of the dust was $40 \%$. This chemical composition was also observed in the fine fraction $(<2.5 \mathrm{~mm}$ diameter), which frequently forms during combustion, thus usually containing larger percentages of carbon than typically found in coarse particles. Remnants of organic matter (e.g. wood, paper, wool and cotton) were also found in the dust samples (e.g. cellulose content of 9 to 20\%). The analyses also show elevated concentrations of products of incomplete combustion (e.g. $>200 \mathrm{mg} \mathrm{g}^{-1}$ total polycyclic aromatic hydrocarbons and $100 \mathrm{ng} \mathrm{g}^{-1}$ of dioxin total equivalents).

\section{RESULTS}

The results from the chamber studies are provided in Table 1. In two empty chamber experiments, vinclozolin flux ranged between 1.5 and $22 \mathrm{ng} \mathrm{m}^{-2} \mathrm{~h}^{-1}$ in the 290 min following fungicide application, yet DCA flux was found to be between 2 and 280ng $\mathrm{m}^{-2} \mathrm{~h}^{-1}$. M1 flux was near detection limits for the entire $1440 \mathrm{~min}$ of the experiments, but M2 flux was found to increase with time, ranging from 0.6 to $120 \mathrm{ng} \mathrm{m}^{-2} \mathrm{~h}^{-1}$. These reactions were more rapid than those observed by Szeto, et al. (1989), and indicate that a number of processes are responsible for degrading vinclozolin. Considerable variability was found for the other scenarios as well, but the presence of clay, soil organic matter 
and other soil components appears to affect the degradation and flux of vinclozolin, as does the presence of microbial populations.

Microbes play important roles in degrading contaminants. For example, Mercadier, et al. (1998) found that the chemical reaction pathway can be mediated by bacteria. A strain of Corynebacterim species was found to degrade vinclozolin to M1butenoic acid, but did not mediate the M2-enanilide reaction. Pseudomonas putida metabolizes vinclozolin as a food carbon source, but has not been observed to degrade the dicarboximide compounds (Cain and Mitchell, 1996). Other species of Pseudomonas have degraded the dicarboximide iprodione (Mercadier, et al., 1997). The rate of microbially mediated hydrolysis is affected by pore fluid $\mathrm{pH}$. Ou, et al. (1997) found that methyl bromide degradation by Nitrosomonas europa was more rapid in limed soils $(\mathrm{pH}$ 7.7) than in acidic (pH 5.5-5.7) soils treated with an ammonia fertilizer $\left(\left(\mathrm{NH}_{4}\right)_{2} \mathrm{SO}_{4}\right)$.

The parent flux was increased by the addition of moisture to the sand column, as was the flux of dichloroaniline (Figure 5), but the flux of the M1-butenoic acid degradate was suppressed.

The largest fluxes were observed following fungicide incorporation, 10\% soil moisture and elevated pore fluid $\mathrm{pH}$. This was found in both sterile soil (Figure 6) and non-sterile soil (Figure 7), but the sterilized soil showed greater vinclozolin flux, while the non-sterile soil showed much greater M1-butenoic acid flux. The total dicarboximide flux was approximately equal for sterile and non-sterile soil, but the chemical speciation was different. The post-application flux of the parent compound vinclozolin was greater in the first 600min from sterilized soil than the parent flux from non-sterile soil under 
these experimental conditions, similar to previous findings in microbial studies (Mercadier, et al. 1998; Mercadier, et al. 1997; Ou et al., 1997; Cain and Mitchell 1996).

The flux of the intermediate degradate M1 was greater for non-sterile soil than for the sterile soil (Figure 6). Accounting for the 31\% greater mass of vinclozolin applied to the sterile soil than the non-sterile soil (6.4 mg versus $4.4 \mathrm{mg}$, respectively). Assuming that the flux is diffusion controlled, the time integrated non-sterile soil versus sterile soil M1 flux for times intervals 10min-5h, 5-10h, and 10-24h was: $110 \mathrm{ng} \mathrm{m}^{-2} \mathrm{~h}^{-1}$ versus 194ng $\mathrm{m}^{-2} \mathrm{~h}^{-1}$; 1.5ng $\mathrm{m}^{-2} \mathrm{~h}^{-1}$ versus $44 \mathrm{ng} \mathrm{m}^{-2} \mathrm{~h}^{-1}$; and $0.3 n g \mathrm{~m}^{-2} \mathrm{~h}^{-1}$ versus $96 \mathrm{ng} \mathrm{m}^{-2} \mathrm{~h}^{-1}$, respectively.

The reduced degradation in the sterile soil in the soil matrix may also be attributed to physical and chemical changes induced by the sterilization process (Alphei and Scheu, 1993). This could have changed the soil-water partitioning coefficients. The non-sterile degradation occurred in the first 300min that continued throughout the entire chamber experiment, however, may emphasize that microbial population adapted to the conditions created by the incorporation process at elevated soil water $\mathrm{pH}$ levels.

For the WTC PAH fluxes, a gas-particle partitioning coefficient is used to describe the distribution of SVOCs between the gas and particle phase. The measured gas-particle partitioning coefficient $\mathrm{K}_{\mathrm{p}}\left(\mathrm{in} \mathrm{m}^{3} \mu \mathrm{g}^{-1}\right)$ is defined as:

$\mathrm{K}_{\mathrm{p}}=\frac{\mathrm{m}_{\mathrm{F}} / \mathrm{m}_{\mathrm{TSP}}}{\mathrm{m}_{\text {gas }}}$

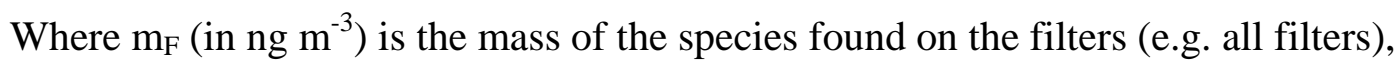
$\mathrm{m}_{\text {gas }}$ is the mass (in $\mathrm{ng} \mathrm{m}^{-3}$ ) of the species found in the gas phase (e.g. denuders) and $\mathrm{m}_{\mathrm{TSP}}$ is the mass of the total suspended particulate matter collected (in $\mu \mathrm{g} \mathrm{m}^{-3}$ ) . 
Determining the mass calibrated to $2.5 \mu$ m was required since a $2.5 \mu \mathrm{m}$ cyclone inlet was used for particle discrimination in the HiC IOGAP sampler. The gas-particle partitioning coefficient has been determined to be a function of the super-cooled liquid vapor pressure $\mathrm{p}_{\mathrm{L}}{ }^{\circ}$, and often has a linear relationship during a sampling event and compound class (Pankow, et al, 1993), such that:

$\log \mathrm{K}_{\mathrm{p}}=\mathrm{m}_{\mathrm{r}} \log \mathrm{p}_{\mathrm{L}}^{\mathrm{o}}+\mathrm{b}_{\mathrm{r}}$

Experimentally the slope $\mathrm{m}_{\mathrm{r}}$ has been determined to be close to -1 , where the intercept $b_{r}$ is typically associated with compound class. The temperature dependent super-cooled liquid vapor pressures $\mathrm{p}_{\mathrm{L}}{ }^{0}$ were taken from Pankow, et al. (1993) or calculated using a Thermophysical Properties Database (American Institute of Chemical Engineers, 2002). Two denuders in series had efficiencies of 98-99\%. Although the $1-2 \%$ breakthrough is small, the effect is greatest when there is a large gas phase component and small particle phase (as in the more volatile compounds). The slope and intercept are in good agreement with other values taken in rural areas (Pankow, et al, 1993) for hydrocarbons. However, there was no meaningful temperature dependence on $\mathrm{K}_{\mathrm{p}}$, within the temperature ranges $16.6-25.6^{\circ} \mathrm{C}$.

\section{DISCUSSION}

The depressed dicarboximide degradation rates at 0 and $20 \%$ soil moistures compared to the rates at $10 \%$ indicate that an optimal moisture range exists for 
vinclozolin degradation. This moisture range may provide for optimal microbial growth and biological activation in the soil column. Likewise, the depressed degradation rates in soil receiving surface applications compared to the degradation rates in soil where the fungicide is incorporated indicates that the harrowing process increases biological activity. The soil moisture and incorporation processes appear to enhance biotic degradation by increasing the contact of microbes to constituents essential to their growth and metabolism: water; nutrients (i.e., the SVOCs); and air. In the non-sterile soil scenario, greater ratios of the both degradates to the parent compound were fluxed into the headspace 10 to 24 hours after the spray event. From pure solutions, one would have expected that the pore water $\mathrm{pH}$ would have driven the degradation process to one or the other degradates, indicating that both acid-catalysis and base-catalysis occurred simultaneously in the same soil column (possibly due to microscopic pockets of high and low $\mathrm{pH}$ pore water).

The soil water $\mathrm{pH}$ affected the geotropospheric SVOC flux, with the greatest flux found at $\mathrm{pH}$ 7.6. Although most of the flux at the higher $\mathrm{pH}$ levels was in the form of the butenoic acid, the enanalide also entered the headspace, albeit at much lower levels than those of the butenoic acid. The delay in the appearance of the enanalide may indicate that the microbial populations degrading vinclozolin to the enanalide take longer to acclimate to the moisture, redox, and $\mathrm{pH}$ conditions in the soil column than those that degrade vinclozolin to M1. For example, the difference in the mean soil pH 7.6 at the beginning of each experiment, but had fallen to $\mathrm{pH} 7.4$ after 1440min. This 0.2 difference in soil $\mathrm{pH}$ may have provided soil conditions sufficient to allow for the acid-catalyzing microbes to grow, especially in pockets of soil with differential $\mathrm{pH}$ levels even lower than the mean 
$\mathrm{pH}$. Differential redox conditions in isolated pockets of the soil column may also account for the microbial growth and consequent enanalide production. These results indicate that the largest flux of the parent SVOC and its degradation products from soil occurs within the first 12 hours after the spray event.

For airborne particle fluxes, much more of the mass finds its way to the gas phase than in the soil fluxes. Table 2 and Figure 8 indicate that for the lighter PAHs (e.g. naphthalene), much larger fractions of the compounds are detected on the XAD-4 sorbant and the second denuders (indications of gas phase concentrations), than on the heavier PAHs (e.g. the benzo pyrenes), where almost all of the mass is captured on quartz filters (indications of particle phase concentrations). So, the role of molecular weight and stereochemistry are critical for determining the likely phase distribution expected after a semivolatile compound has reached the troposphere.

Thus, the results of these two scenarios indicate that temperature, $\mathrm{pH}$, and microbial factors loom large in the soil but are lesser factors once an SVOC has found its way to the troposphere. Time may well be a factor, but both measurement designs were based upon 24-hour integrated samples. Flow within the systems may also influence advective and diffusive properties, with the soil closer to laminar conditions and the atmosphere very likely to be turbulent. Particle size may also be a factor, as most of the particles measured in the troposphere were less than $2.5 \mu \mathrm{m}$ in aerodynamic diameter, but the soil and sand matrices contained a wide range of particles, many with diameters much larger than $2.5 \mu \mathrm{m}$. Thus, surface phenomena may not be comparable.

The $\mathrm{K}_{\mathrm{p}}$ values, corrected for denuder breakthrough, were compared to the ideal vapor pressures (i.e. super-cooled), as shown in Figure 9. There is an apparent correlation 
between particle-gas phase distribution and vapor pressure $\left(r^{2}=0.81\right)$. However, other equilibrium constants are important in the fate of SVOCs. For example, the respective Henry's Law $\left(\mathrm{K}_{\mathrm{H}}\right)$ constants for vinclozolin and benzo(a)pyrene of $5.44 \times 10^{-7}$ and $1.87 \times$ $10^{-5}$ indicate that these SVOC's low solubility and low vapor pressure will keep the compound in the particle phase. Sorption is also important for both the soil particle and aerosol.

The results indicate that factors influencing particle-gas phase distribution in the soil compartment can differ from that in the atmosphere. Particle physics and chemistry play roles in both environmental media, but the factors are not comparable. Molecular weight and structure influence the amount and rate of geotropospheric flux, but in different ways in the two media. The molecular weight relationship to atmospheric phase distribution between particles and gases is consistent with the data collected at WTC for other compounds. This is not only observed in aromatic compounds. For example, $n$ alkanes were also measured downwind of the WTC using the IOGAP (Figure 10). Recalling that the quartz filter without sorbant exclusively collects particles and no gases, compounds with 27 or more carbon atoms exist only as particulate matter under environmental conditions. The longer the carbon chain and, greater the molecular weight, the more likely the alkane molecule would remain in the particle phase, i.e. the greater the number of carbon atoms in the molecule, the less mass was distributed to the gas phase during geotropospheric flux.

Another important consideration when analyzing SVOC phase distribution is the interpretation of denuder breakthrough. This is principally a problem for the more volatile (i.e. lower molecular weight) compounds, e.g. naphthalene. Breakthrough from 
one denuder to the next is temperature-dependent and can be affected by periodic changes in concentration (e.g. a "slug" of SVOC mass), similar to the separation on a GC column. To quantify breakthrough bias, simultaneous sampling with SVOC monitoring devices is preferred, one with the experimental set-up as described in the Methods section and one with a Teflon filter at the inlet to give an exclusive measure of the breakthrough mass only. However, in light of the WTC emergency response needs and the availability of only one IOGAP monitor in this study, denuders in series were used instead. This provided an estimate of real-time denuder breakthrough, i.e. if more mass of a compound was found on the second denuder than on the first, breakthrough had occurred (Stockburger, 2004).

The comparison of the SVOC flux results in Table 1 to the SVOC phase distribution results in Table 2 indicates that the fugacity (i.e. leaving tendency from the particle to the gas phase) of SVOCs is not completely predictable from published values of the compounds' vapor pressures, although they may be useful for hydrophobic substances like the PAHs. Water solubility also plays a role in phase distribution, so Henry's Law constants $\left(\mathrm{K}_{\mathrm{H}}\right)$ may be more robust predictors of phase distribution to the gas phase than vapor pressures. The affinity for the gas phase from either a particle in a soil matrix or from a hydroscopic nucleus in the atmosphere may be affected by solubility. Since $\mathrm{K}_{\mathrm{H}}$ takes into account a substance's vapor pressure and hydrophilicity, it would be expected to differ from vapor pressure alone. This was tested for seven PAHs: fluorene; phenanthrene; anthracene; fluoranthene; pyrene; benz(a)anthracene; and chrysene, for which vapor pressure and dimensionless $\mathrm{K}_{\mathrm{H}}$ values are published. The experimental $K_{p}$ values were plotted against vapor pressures (Figure 11) and against $K_{H}$ 
values. No difference was found. The regression was nearly identical $\left(r^{2}=0.72\right.$ for vapor pressure and $r^{2}=0.73$ for $K_{H}$ ). Neither regression was a strong as the relationship between and the calculated super-cooled liquid vapor pressures in Figure 9. However, since all seven of these PAHs are very hydrophobic, it appears that solubility in water is not a factor. One may expect to see $\mathrm{K}_{\mathrm{H}}$ as a more robust predictor of particle-gas distribution of more hydrophilic compounds than vapor pressure alone.

Another important factor is sorption, which was not specifically addressed in either the soil or the aerosol studies. Highly sorptive compounds will be less likely to move from the particle to the troposphere, all other factors being equal. For example, liquid to solid phase partitioning coefficient is the organic carbon partitioning coefficient $\left(\mathrm{K}_{\mathrm{oc}}\right)$, which is the ratio of the contaminant concentration sorbed to organic matter in the matrix (soil or sediment) to the concentration in the aqueous phase. Thus, the $\mathrm{K}_{\mathrm{oc}}$ is derived from the quotient of a contaminant's $\mathrm{K}_{\mathrm{d}}$ and the fraction of organic matter (OM) in the matrix:

$\mathrm{K}_{\mathrm{oc}}=\frac{\mathrm{K}_{\mathrm{d}}}{\mathrm{OM}}$

These coefficients are frequently reported as single value (e.g. the Pesticide Action Network (2004) reports vinclozolin’s $\mathrm{K}_{\mathrm{oc}}$ to be 260). However, care must be taken when applying $\mathrm{K}_{\mathrm{oc}}$ values because they $\mathrm{K}_{\mathrm{oc}}$ will vary from matrix to matrix, i.e. $\mathrm{K}_{\mathrm{oc}}$ is not entirely an inherent property of the compound. For example, a recent study (McNamara, et al., 2002) found $\mathrm{K}_{\mathrm{oc}}$ of the $\mathrm{PAH}$, phenanthrene to range nearly three orders of 
magnitude, depending on the matrix (log $\mathrm{K}_{\mathrm{oc}}=7$ for granulated activated carbon (GAC) to 4.3 for soil OM). This also indicates the availability of promising methods to collect and treat SVOCs, since GAC has such a strong affinity to PAHs.

It is important to note the large variability and uncertainty in the data sets, making direct comparisons difficult. For example, the values in Tables 1 and 2 have large ranges and wide confidence intervals. Some uncertainty can be attributed to variability in soils. For example, even if samples are collected from the same soil type, composition of clay, soil organic matter, and physical factors such as porosity can vary considerably (Weaver, et al., 2004). Also, soils were dosed with the constant volumes of pesticide suspensions, but as noted in the original study, there was a range in the actual amount of parent compound and inert ingredients, and although considerable efforts were made to avoid co-elution and other analytical error, the possibility of incorrect peak identification and quantitation exists. Extraction is also uncertain, since the amount of each analyte recovered varies according to soil type and the existence of unidentified and uncontrolled laboratory conditions. Such possibilities increase the uncertainty of phase distribution from the soil matrix to the headspace. Finally, the day-to-day variances in the atmospheric measurements (e.g. see Table 2 and Figure 9) of SVOC concentrations were considerable. Such uncertainty is common with measurements in environmental media.

The study results point to the advantage of using experimentally derived phase distribution values for modeling geotropospheric flux of SVOCs. However, for SVOCs with low water solubility, both vapor pressure and Henry’s Law constants may be acceptable parameters for predicting the movement from either the soil matrix and from 
an airborne particle to the troposphere. The research also demonstrates that laboratory and field measurements of SVOCs can be used to characterize phase distribution behavior in matrices and the open atmosphere. Results from both study designs are useful in applying theoretical concepts, such as molecular configurations, to actual observations in the field, e.g. SVOC concentrations in a plume.

\section{ACKNOWLEDGMENTS}

The author would like to thank Leonard Stockburger and Erick Swartz, of the U.S. Environmental Protection Agency's National Exposure Research Laboratory in Research Triangle Park, NC, and Jeffrey Peirce of Duke University’s Department of Civil and Environmental Engineering for the collaborations and the use of our research results in this meta-analysis. This work has been funded in part by EPA. It has been subjected to Agency review and approved for publication. Mention of trade names or commercial products does not constitute endorsement or recommendation for use. 


\section{REFERENCES}

ALPHEI, J. and SCHEU, S. (1993). "Effects of biocidal treatments on biological and nutritional properties of a mull-structured woodland soil.” Geoderma, 56: 435-448. AMERICAN INSTITUTE OF CHEMICAL ENGINEERS (2002). DIPPR Project 801, Thermophysical Properties Database, Release, January 2002.

BASF CORPORATION (1997). Supplemental label: Ronalin ${ }^{\circledR}$ DF fungicide. EPA Reg. No. 7969-85, EPA Establishment No. 39578-WG-01.

CAIN, R.B. and MITCHELL, J.A. (1996). Enhanced degradation of the fungicide vinclozolin: isolation and characterization of the responsible organism. Pestic. Sci., 48: $13-23$.

GUNDEL L.A. (1998). Standard operating procedures for coating annular denuders with XAD-4 resin; US EPA Chemical Speciation Program, PUB-3143.

GUNDEL, L.A.; DAISEY, J.M. and STEVENS, R.K. (1998). Quantitative Organic Vapor-Particle Sampler, US Patent 5,763,360.

GUNDEL, L.A.; DAISEY, J.M. and STEVENS, R.K. (2001). Method for fabricating a quantitative integrated diffusion vapor-particle sampler for sampling, detection and quantitation of semi-volatile organic gases, vapors and particulate components, US Patent 6,226,852.

HEMOND, H.F. and FECHNER, E.J. (1996). Chemical fate and transport in the environment. Academic Press, San Diego, CA. 
LEWIS, R.G. and GORDON, S.M. (1996). "Sampling for organic chemicals in air.”

Principles of Environmental Sampling. Ed.: American Chemical Society:

Washington, DC, 401-470.

LIOY, P., WEISEL, C., MILLETTE, J. EISENREICH, S., VALLERO, D.,

OFFENBERG, J., BUCKLEY, B., TURPIN, B., ZHONG, M., COHEN, M.,

PROPHETE, C., YANG, I., STILES, R., CHEE, G., JOHNSON, W.,

ALIMOKHTARI, S. WESCHLER, C., and CHEN, L. (2002). Characterization of the dust/smoke aerosol that settled east of the World Trade Center (WTC) in Lower Manhattan after the collapse of the 11 September 11 2001. Environmental Health Perspectives. 110 (7), 703-714.

McLEAN, E.O. (1982) Soil pH and lime requirement. In: Methods of Soil Analysis, Part 2: Chemical and Microbiological Properties. Monograph 9. American Society of Agronomy, Inc., Soil Science Society of America, Inc.: Madison, WI, 199-215. MERCADIER, C., VEGA, D., and BASTIDE, J. (1998).Chemical and biological transformation of the fungicide vinclozolin. J. Agric. Food Chem., 46: 3817-3822. MERCADIER, C., VEGA, D., and BASTIDE, J (1997). Iprodione degradation by isolated soil microorganisms. FEMS Microbiol. Ecol., 23: 207-215.

OU, L-T., JOY, P.I., THOMAS, J.E. and HORNSBY, A.G. (1997). Stimulation of microbial degradation of methyl bromide in soil during oxidation of an ammonia fertilizer by nitrifiers. Environ. Sci. Technol, 31: 717-722.

PANKOW, J.F., STOREY, J.M.E., and YAMSASKI, H. (1993). Effects of relative humidity on gas/particle partitioning of semivolatile organic compounds to urban particulate matter Environ. Sci. Tech., 27: 2220-2226. 
PESTICIDE ACTION NETWORK. (2004). Vinclozolin.

http://www.pesticideinfo.org/Detail_Chemical.jsp?Rec_Id=PC35425. Accessed April

30, 2004.

STOCKBURGER, L. (2004). Personal communication, April 29, 2004.

SWARTZ, E., STOCKBURGER, L., and GUNDEL, L.A. (2003). Recovery of

Semivolatile Organic Compounds during Sample Preparation: Implications for

Characterization of Airborne Particulate Matter. Environ. Sci. Technol., 37: 597605.

SWARTZ, E., STOCKBURGER, L. and VALLERO, D. (2003). Polyaromatic hydrocarbons and other semi-volatile organic compounds collected in New York City in response to the events of 9/11. Environ. Sci. Technol., 37 (16): 35373546.

SZETO, S.Y., BURLINSON, N.E., RAHE, J.E., and OLOFFS, P.C. (1989). Kinetics of hydrolysis of the dicarboximide fungicide vinclozolin. J. Agric. Food Chem., 37: 523529.

VALLERO, D. and PEIRCE, J. (2002) Transformation and transport of vinclozolin from soil to air. Journal of Environmental Engineering, 128 (3): 261-268.

WEAVER, A.R., KISSEL, D., CHEN, F., WEST, T, ADKINS, W., RICKMAN, D, AND LUVALL, J.C. (2004) Mapping Soil pH Buffering Capacity of Selected Fields in the Coastal Plain. Soil Sci. Soc. Am. J. 68: 662-668.

WILLIAMS, R.W., WATTS, R.R., STEVENS, R.K., STONE, C.L., and LEWTAS, J. (1999). "Evaluation of personal air sampler for twenty-four hour collection of fine particles and semivolatile organics.” J. Expos. Anal. Environ. Epidemiol., 2: 158-166. 


\section{NOTATION}

The following symbols are used in this paper:

\begin{tabular}{|c|c|c|}
\hline A & $=$ & surface area of soil-air interface \\
\hline$[\mathrm{C}]$ & $=$ & chemical concentration \\
\hline $\mathrm{D}$ & $=$ & chemical destruction rate \\
\hline $\mathrm{H}$ & $=$ & headspace height \\
\hline $\mathrm{J}$ & $=$ & soil-to-air flux \\
\hline $\mathrm{K}$ & $=$ & partitioning coefficient \\
\hline $\mathrm{M}$ & $=$ & mass \\
\hline Q & $=$ & airflow \\
\hline $\mathrm{p}_{\mathrm{L}}$ & $=$ & super-cooled liquid vapor pressure \\
\hline $\mathrm{R}$ & $=$ & chemical production rate \\
\hline $\mathrm{V}$ & $=$ & volume \\
\hline$\Psi$ & $=$ & surface deposition \\
\hline
\end{tabular}

\section{Subscripts}

$\begin{array}{lll}\text { A } & = & \text { headspace air } \\ 0 & = & \text { inlet } \\ \mathrm{f} & = & \text { outlet } \\ \mathrm{F} & = & \text { filter fraction } \\ \text { gas } & = & \text { gas phase fraction } \\ \mathrm{H} & = & \text { Henry's Law partitioning } \\ \mathrm{L} & = & \end{array}$


OC

p

TSP

Superscripts
$=$

$=$

$=$

$=$

$=$ organic-carbon partitioning

particle-gas partitioning

total suspended particulate

SVOC

semi-volatile organic compound

headspace surface area 
Figure Captions

Figure 1: Structures of dicarboximide compounds (from Edlich and Lyr, 1992) and the general configuration of polycyclic aromatic hydrocarbons (benzo(a)pyrene is shown).

Figure 2. Schematic of experimental setup for semi-volatile organic compound flux chamber.

Figure 3. Polycyclic aromatic hydrocarbon samples were collected outdoors at 290 Broadway, Lower Manhattan, New York on the $16^{\text {th }}$ floor. Other samples were collected at Ground Zero (A, C, and K), but are not reported here.

Figure 4. Schematic of the high capacity Integrated Organic Gas and Particulate (HiC IOGAP) sampler with a $2.5 \mu \mathrm{m}$ cyclone inlet for particle discrimination was used in Lower Manhattan, NY to collect semi-volatile gases and particles for speciation of organic compounds. The sampler utilizes two sorbant (XAD-4) coated eight-channel annular denuders (52 $\mathrm{mm}$ outer diameter, $285 \mathrm{~mm}$ length) to collect the gas phase species and a pre-baked quartz filter followed by three XAD-4 impregnated quartz filters to collect the particle phase. The XAD-4 impregnated quartz filters were used to collect those compounds that desorb from the particles on the quartz filters and/or not removed by the denuders. The volumetric flow rate of the HIC IOGAP sampler was set to $85 \mathrm{Lmin}^{-1}$ and temperature controlled at $4^{0} \mathrm{C}$ 
above ambient to prevent condensation of water. (Drawing used with permission by URG Corporation.)

Table 1. Flux of dicarboximide compounds following fungicide application in a chamber.

Figure 5. Time integrated flux of dicarboximides from sterile 20-30mesh Ottawa sand at $3 \%$ moisture (A) and with the $10 \% \mathrm{pH} 7.5$ pore fluid (B), following soil incorporation of $5 \mathrm{~mL}$ of $2000 \mathrm{mg} \mathrm{L}^{-1}$ amide fungicide/water suspension. Error bars indicate 95\% confidence intervals calculated from two duplicates; i.e., experiments with identical rain effects, pore fluid $\mathrm{pH}$, soil type, pesticide application technique, and sterilization.

Figure 6. Time integrated flux of dicarboximides from sterilized soil with pore water pH 7.5, following incorporation of $5 \mathrm{~mL}$ of $2000 \mathrm{mg} \mathrm{L}^{-1}$ amide fungicide/water suspension and a $2.8 \mathrm{~mm}$ rain event. Error bars indicate $95 \%$ confidence intervals calculated from two duplicates; i.e., experiments with identical rain effects, pore fluid pH, soil type, pesticide application technique, and sterilization.

Figure 7. Time integrated flux of dicarboximides from non-sterile soil with pore water $\mathrm{pH} 7.5$, following incorporation of $5 \mathrm{~mL}$ of $2000 \mathrm{mg} \mathrm{L}^{-1}$ amide fungicide/water suspension and a $2.8 \mathrm{~mm}$ rain event. Error bars indicate $95 \%$ confidence intervals. 
Figure 8. Average concentration of polycyclic aromatic hydrocarbons sampled at lower Manhattan, September 26 and 27, 2001. Generally, molecular weight increases from left to right. Note broken bar between 60 and $200 \mathrm{ng} \mathrm{m}^{-3}$ concentrations.

Figure 9. Relationship of gas-particle partitioning coefficient $\left(K_{p}\right)$ as a function of super-cooled liquid vapor pressure $\left(p_{L}\right)$ for semivolatile organic compounds collected in the troposphere downwind from the World Trade Center fire. Note: The $K_{p}$ values have been corrected for denuder breakthrough.

Figure 10. Concentrations of $n$-alkanes in the plume downwind from the World Trade Center, indicating phase distribution. The quartz filter without sorbant material indicates exclusive particle matter. Third XAD-4 impregnated filter, due to breakthrough, indicates almost exclusively gas phase matter. Note broken bar between 60 and $200 \mathrm{ng} \mathrm{m}^{-3}$ concentrations.

Figure 11. Relationship of measured gas-particle partitioning coefficients $\left(K_{p}\right)$ to published vapor pressures for seven polycyclic aromatic hydrocarbons found in the troposphere downwind from the World Trade Center fire.

Figure 12. Relationship of gas-particle partitioning coefficients $\left(K_{p}\right)$ to published dimensionless Henry’s Law constants for seven polycyclic aromatic hydrocarbons found in the troposphere downwind from the World Trade Center fire. 

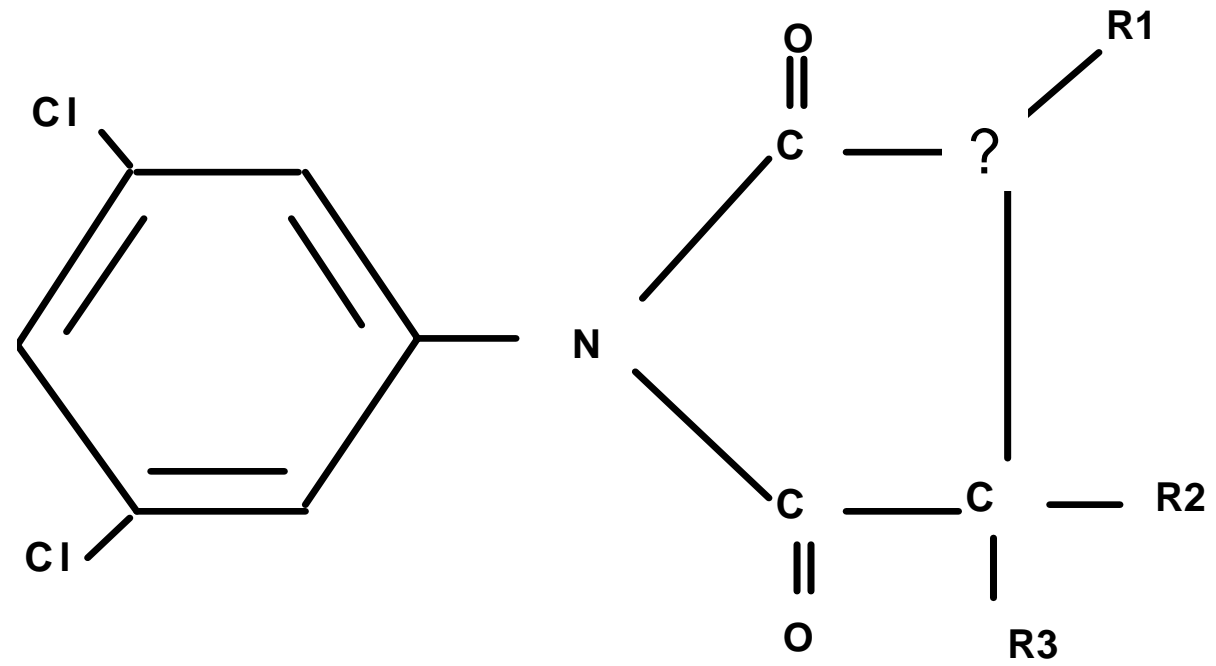

\section{Dicarboximides}

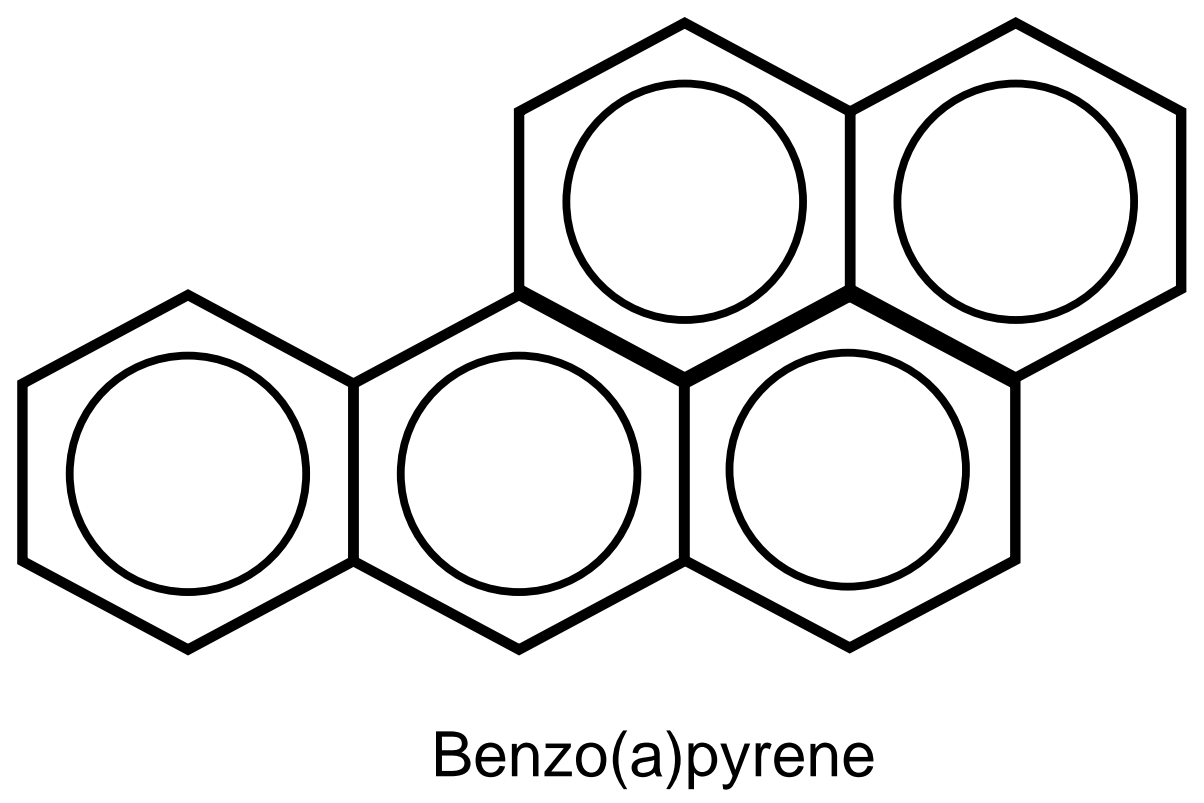

Figure 1: Structures of dicarboximide compounds (from Edlich and Lyr, 1992) and the general configuration of polycyclic aromatic hydrocarbons (benzo(a)pyrene is shown). 


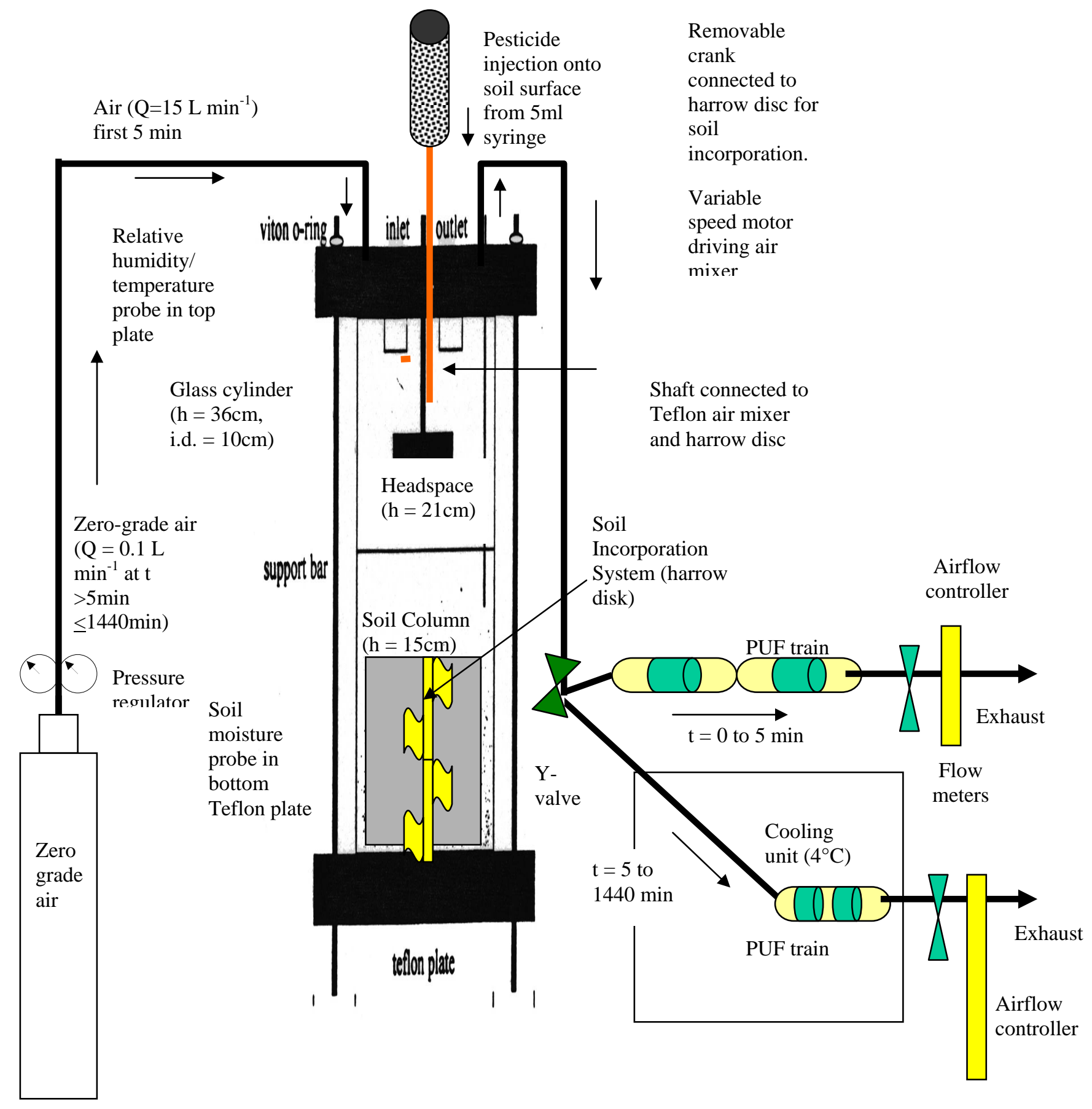

Figure 2. Schematic of experimental setup for semi-volatile organic compound flux chamber. 


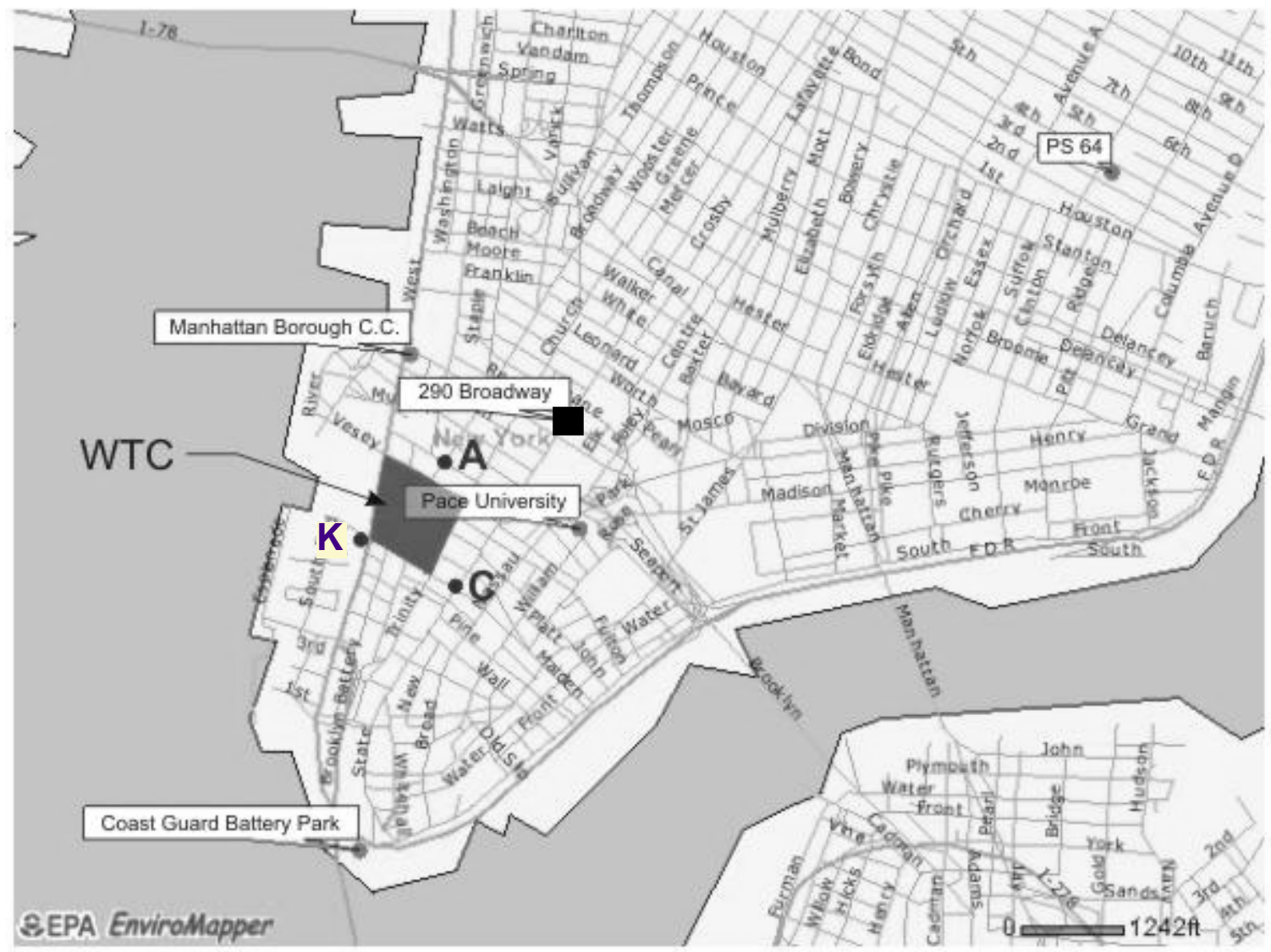

Figure 3. Polycyclic aromatic hydrocarbon samples were collected outdoors at 290

Broadway, Lower Manhattan, New York on the $16^{\text {th }}$ floor. Other samples were collected at Ground Zero (A, C, and $\mathrm{K}$ ), but are not reported here. 


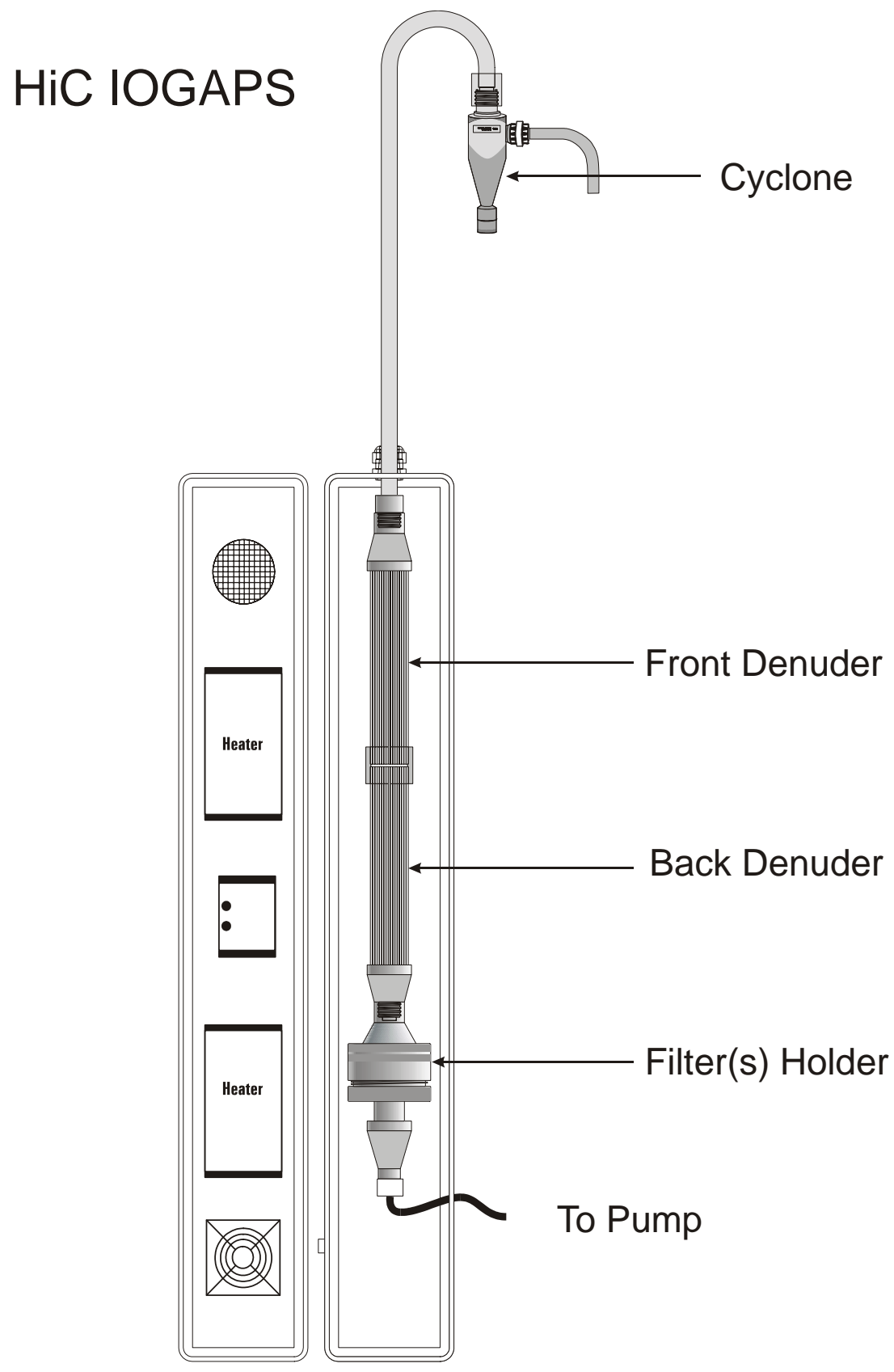

Figure 4. Schematic of the high capacity Integrated Organic Gas and Particulate (HiC IOGAP) sampler with a $2.5 \mu \mathrm{m}$ cyclone inlet for particle discrimination was used in Lower Manhattan, NY to collect semi-volatile gases and particles for speciation of organic compounds. The sampler utilizes two sorbant (XAD-4) coated 
eight-channel annular denuders (52 $\mathrm{mm}$ outer diameter, $285 \mathrm{~mm}$ length) to collect the gas phase species and a pre-baked quartz filter followed by three XAD-4 impregnated quartz filters to collect the particle phase. The XAD-4 impregnated quartz filters were used to collect those compounds that desorb from the particles on the quartz filters and/or not removed by the denuders. The volumetric flow rate of the HIC IOGAP sampler was set to $85 \mathrm{~L} \mathrm{~min}^{-1}$ and temperature controlled at $4^{\circ} \mathrm{C}$ above ambient to prevent condensation of water. (Drawing used with permission by URG Corporation.) 
Table 1. Flux of dicarboximide compounds following fungicide application in a

chamber.

\begin{tabular}{|c|c|c|c|c|c|c|c|}
\hline \multirow{2}{*}{$\begin{array}{l}\text { Time } \\
\text { interval } \\
\text { since } \\
\text { spray } \\
\text { event } \\
\text { (min) }\end{array}$} & \multirow{2}{*}{\multicolumn{2}{|c|}{$\begin{aligned} & \text { Pore } \\
& \text { fluid } \\
& \text { n } \text { pH } \\
&\end{aligned}$}} & \multirow[b]{2}{*}{$\begin{array}{l}\text { Mean } \\
\text { percent } \\
\text { moisture } \\
\text { in soil } \\
\text { column }\end{array}$} & \multicolumn{4}{|c|}{$\begin{array}{l}\text { Mean integrated flux }\left(\mathrm{ng} \mathrm{m}^{-2} \mathrm{~h}^{-1}\right) \pm 95 \% \text { confidence } \\
\text { interval }\end{array}$} \\
\hline & & & & Vinclozolin & $\begin{array}{l}\text { M1-butenoic } \\
\text { acid }\end{array}$ & M2-enanilide & 3,5-DCA \\
\hline & & & & \multicolumn{4}{|c|}{ Fungicide sprayed onto unsterile soil (not incorporated) } \\
\hline \multirow[t]{5}{*}{$10-300$} & 2 & 6.3 & 0 & $52.6 \pm 28.1$ & $27.3 \pm 10.3$ & $1.0 \pm 0.0$ & $11.2 \pm 6.5$ \\
\hline & 2 & 4.7 & 10 & $60.5 \pm 34.9$ & $65.8 \pm 49.7$ & $0.5 \pm 0.0$ & $61.1 \pm 59.8$ \\
\hline & 2 & 4.7 & 20 & $13.1 \pm 0.8$ & $11.8 \pm 5.1$ & $0.7 \pm 0.0$ & $8.2 \pm 0.7$ \\
\hline & 3 & 7.5 & 10 & $211.6 \pm 188.4$ & $43.7 \pm 21.0$ & $135.3 \pm 120.5$ & $17.5 \pm 4.2$ \\
\hline & 2 & 7.5 & 20 & $21.6 \pm 20.3$ & $62.7 \pm 6.6$ & $17.1 \pm 16.1$ & $14.8 \pm 14.4$ \\
\hline \multirow[t]{5}{*}{$300-600$} & 2 & 6.3 & 0 & $67.7 \pm 40.5$ & $12.3 \pm 9.3$ & $0.5 \pm 0.0$ & $6.4 \pm 0.3$ \\
\hline & 2 & 4.7 & 10 & $4.0 \pm 1.6$ & $4.0 \pm 1.3$ & $0.1 \pm 0.0$ & $0.8 \pm 0.8$ \\
\hline & 2 & 4.7 & 20 & $100.8 \pm 85.3$ & $5.6 \pm 4.2$ & $0.7 \pm 0.0$ & $6.0 \pm 0.9$ \\
\hline & 3 & 7.5 & 10 & $103.7 \pm 91.9$ & $29.7 \pm 18.6$ & $0.4 \pm 0.0$ & $8.6 \pm 1.8$ \\
\hline & 2 & 7.5 & 20 & $24.1 \pm 11.8$ & $15.1 \pm 7.4$ & $0.0 \pm 0.0$ & $5.3 \pm 2.6$ \\
\hline \multirow{6}{*}{$\begin{array}{l}600- \\
1440\end{array}$} & 2 & 6.3 & 0 & $12.8 \pm 1.0$ & $5.1 \pm 4.7$ & $1.2 \pm 1.1$ & $0.9 \pm 0.4$ \\
\hline & 2 & 4.7 & 10 & $29.0 \pm 14.9$ & $25.1 \pm 0.2$ & $0.5 \pm 0.0$ & $7.9 \pm 2.4$ \\
\hline & 2 & 7.5 & 20 & $1.6 \pm 0.7$ & $2.7 \pm 1.3$ & $1.2 \pm 0.6$ & $0.7 \pm 0.3$ \\
\hline & 3 & 7.5 & 10 & $17.1 \pm 13.0$ & $2.9 \pm 0.0$ & $0.1 \pm 0.0$ & $1.0 \pm 1.0$ \\
\hline & 2 & 4.7 & 20 & $4.0 \pm 0.5$ & $2.7 \pm 1.8$ & $0.0 \pm 0.0$ & $1.6 \pm 0.7$ \\
\hline & & & & \multicolumn{4}{|c|}{ Fungicide incorporated into unsterile soil } \\
\hline \multirow[t]{5}{*}{$10-300$} & 2 & 6.3 & 0 & $90.2 \pm 5.1$ & $0.0 \pm 0.0$ & $0.0 \pm 0.0$ & $63.6 \pm 3.0$ \\
\hline & 2 & 4.7 & 10 & $26.1 \pm 11.9$ & $24.5 \pm 8.9$ & $1.4 \pm 0.8$ & $11.4 \pm 5.3$ \\
\hline & 2 & 7.5 & 10 & $30.1 \pm 28.7$ & $196.4 \pm 124.9$ & $0.6 \pm 0.0$ & $102.2 \pm 67.8$ \\
\hline & 2 & 4.7 & 20 & $158.3 \pm 142.5$ & $25.2 \pm 4.1$ & $19.4 \pm 18.3$ & $10.2 \pm 7.8$ \\
\hline & 2 & 7.5 & 20 & $34.0 \pm 25.4$ & $14.7 \pm 0.7$ & $0.7 \pm 0.0$ & $5.6 \pm 1.8$ \\
\hline \multirow[t]{5}{*}{$300-600$} & 2 & 6.3 & 0 & $84.3 \pm 3.3$ & $0.0 \pm 0.0$ & $0.0 \pm 0.0$ & $59.4 \pm 2.8$ \\
\hline & 2 & 4.7 & 10 & $23.7 \pm 1.0$ & $13.3 \pm 2.0$ & $33.2 \pm 7.4$ & $0.5 \pm 0.0$ \\
\hline & 2 & 7.5 & 10 & $3.5 \pm 2.8$ & $45.0 \pm 15.4$ & $0.5 \pm 0.0$ & $43.0 \pm 19.6$ \\
\hline & 2 & 4.7 & 20 & $8.7 \pm 2.3$ & $8.2 \pm 2.8$ & $0.4 \pm 0.0$ & $3.4 \pm 1.9$ \\
\hline & 2 & 7.5 & 20 & $20.1 \pm 7.4$ & $22.2 \pm 6.2$ & $0.6 \pm 0.0$ & $11.5 \pm 1.1$ \\
\hline $600-$ & 2 & 6.3 & 0 & $21.6 \pm 0.8$ & $0.1 \pm 0.0$ & $0.1 \pm 0.0$ & $15.2 \pm 0.5$ \\
\hline
\end{tabular}


1440

$\begin{array}{lllllll}2 & 4.7 & 10 & 3.3 \pm 1.4 & 5.1 \pm 2.3 & 0.1 \pm 0.0 & 1.6 \pm 0.8 \\ 2 & 7.5 & 10 & 5.2 \pm 5.0 & 97.1 \pm 80.2 & 29.1 \pm 27.0 & 56.1 \pm 47.7 \\ 2 & 4.7 & 20 & 2.6 \pm 0.2 & 4.2 \pm 1.5 & 0.1 \pm 0.0 & 1.3 \pm 0.3 \\ 2 & 7.5 & 20 & 0.1 \pm 0.0 & 0.3 \pm 0.1 & 0.3 \pm 0.0 & 0.4 \pm 0.2\end{array}$

Fungicide incorporated into sterile soil

$\begin{array}{lll}10-300 & 2 & 7.5 \\ 300-600 & 2 & 7.5 \\ 600- & 2 & 7.5 \\ 1440 & & \end{array}$

$10-300 \quad 2 \quad 7.0$

38.8

$300-600 \quad 2 \quad 7.0$

38.8

$600-\quad 27.0$

1440

38.8

$\begin{array}{lll}10-300 & 2 & 7.0\end{array}$

$300-600 \quad 2 \quad 7.0$

$600-\quad 27.0$

1440 $\begin{array}{ll}10 & 118.0 \pm 115.7 \\ 10 & 215.1 \pm 80.1\end{array}$

$84.1 \pm 81.1$

$0.7 \pm 0.0$

$1.2 \pm 0.0$

$0.6 \pm 0.0$

$0.1 \pm 0.0$

$10 \quad 0.1 \pm 0.0$

$0.2 \pm 0.0$

Fungicide incorporated into sterile sand

$\begin{array}{rllll}0 & 13.0 \pm 1.8 & 3.8 \pm 2.8 & 0.6 \pm 0.1 & 7.4 \pm 7.2 \\ 10 & 72.0 \pm 26.4 & 1.1 \pm 0.0 & 2.0 \pm 1.4 & 4.9 \pm 4.7 \\ 0 & 7.4 \pm 7.2 & 8.1 \pm 6.5 & 0.6 \pm 0.0 & 7.4 \pm 7.2 \\ 10 & 81.2 \pm 3.0 & 1.1 \pm 0.0 & 0.6 \pm 0.0 & 52.4 \pm 25.7 \\ 0 & 0.7 \pm 0.6 & 1.5 \pm 1.0 & 1.0 \pm 0.0 & 1.9 \pm 0.2\end{array}$

$10 \quad 3.4 \pm 2.2$

$0.5 \pm 0.2$

$1.8 \pm 0.9$

$1.4 \pm 0.7$
$45.6 \pm 44.5$.

$0.1 \pm 0.0$

$0.0 \pm 0.0$

\section{Fungicide applied to empty chamber (no soil)}

$\begin{array}{lllll}0 & 11.9 \pm 10.2 & 2.3 \pm 1.1 & 0.6 \pm 0.0 & 142.6 \pm 137.6 \\ 0 & 5.3 \pm 3.8 & 2.3 \pm 1.0 & 119.1 \pm 116.1 & 5.7 \pm 7.9 \\ 0 & 0.5 \pm 0.0 & 0.8 \pm 0.4 & 42.5 \pm 41.5 & 0.7 \pm 0.1\end{array}$



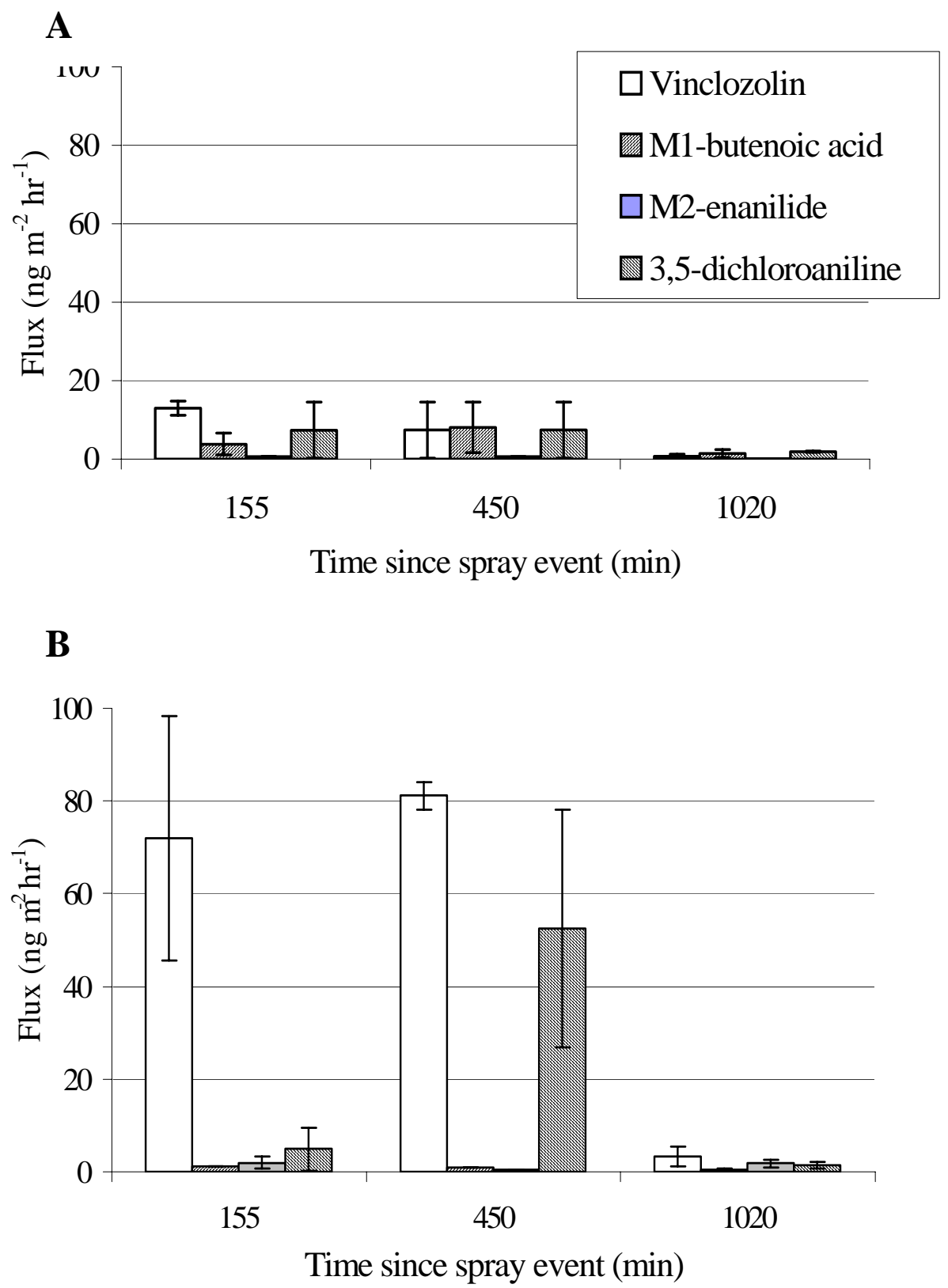

Figure 5. Time integrated flux of dicarboximides from sterile 20-30mesh Ottawa sand at $3 \%$ moisture (A) and with the $10 \% \mathrm{pH7.5}$ pore fluid (B), following soil incorporation of $5 \mathrm{~mL}$ of $2000 \mathrm{mg} \mathrm{L}^{-1}$ amide fungicide/water suspension. Error bars 
indicate $95 \%$ confidence intervals calculated from two duplicates; i.e., experiments with identical rain effects, pore fluid $\mathrm{pH}$, soil type, pesticide application technique, and sterilization. 


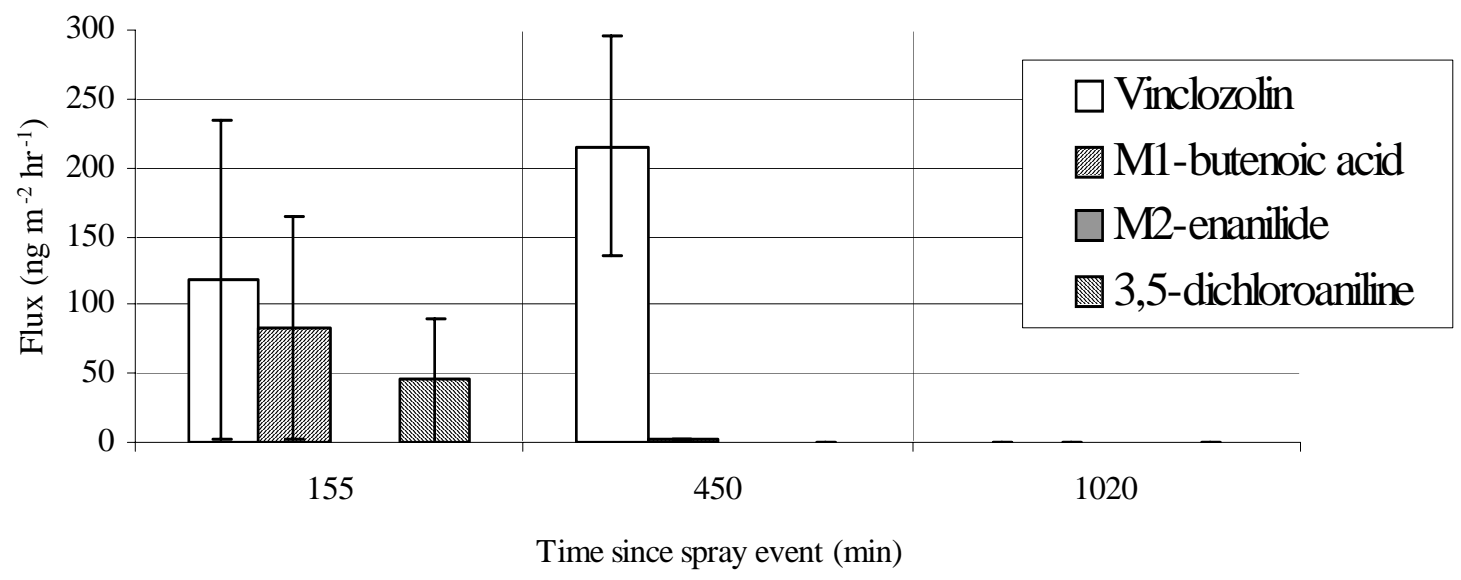

Figure 6. Time integrated flux of dicarboximides from sterilized soil with pore water pH7.5, following incorporation of $5 \mathrm{~mL}$ of $2000 \mathrm{mg} \mathrm{L}^{-1}$ amide fungicide/water suspension and a $2.8 \mathrm{~mm}$ rain event. Error bars indicate $95 \%$ confidence intervals calculated from two duplicates; i.e., experiments with identical rain effects, pore fluid pH, soil type, pesticide application technique, and sterilization. 


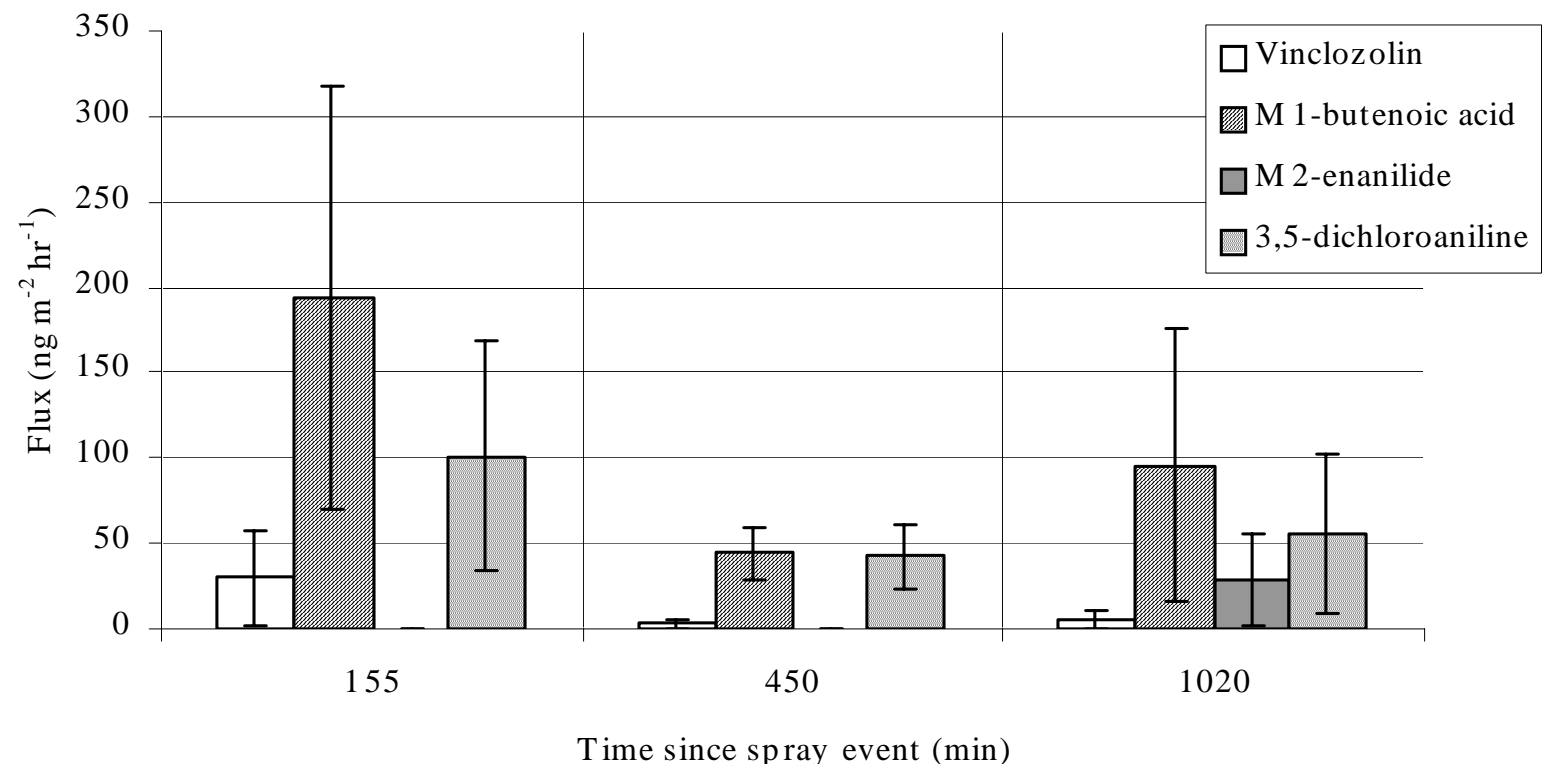

Figure 7. Time integrated flux of dicarboximides from non-sterile soil with pore water $\mathrm{pH} 7.5$, following incorporation of $5 \mathrm{~mL} \mathrm{of} 2000 \mathrm{mg} \mathrm{L}^{-1}$ amide fungicide/water suspension and a $2.8 \mathrm{~mm}$ rain event. Error bars indicate $95 \%$ confidence intervals. 
Table 2. Total concentrations $\left(\mathrm{ng} \mathrm{m}^{-3}\right.$ ) of PAHs measured at Lower Manhattan, New York (italicized data represents particle-only concentrations).

\begin{tabular}{|c|c|c|c|c|c|}
\hline \multirow[t]{2}{*}{ Dates } & $\begin{array}{l}09 / 26- \\
09 / 27\end{array}$ & \multicolumn{4}{|c|}{$10 / 04-10 / 0510 / 06-10 / 0710 / 12-10 / 1310 / 20-10 / 21$} \\
\hline & Total & Total & Total & Total & Total \\
\hline Naphthalene $^{\mathrm{o}}$ & $699(34)$ & $824(405)$ & 109 & 22 & 42 \\
\hline 2-Methyl naphthalene ${ }^{\mathrm{o}}$ & $267(6)$ & $323(37)$ & 54 & 37 & 165 \\
\hline 1-Methyl naphthalene ${ }^{\mathrm{o}}$ & $178(5)$ & $212(27)$ & 29 & 11 & 103 \\
\hline Biphenyl $^{\circ}$ & $182(4)$ & $224(9)$ & 11 & 90 & 190 \\
\hline 2-Ethyl naphthalene* & $42(1)$ & $42(1)$ & 7 & 30 & 46 \\
\hline 1-Ethyl naphthalene* & $17(1)$ & $24(1)$ & 4 & 10 & 26 \\
\hline 2,6-dimethyl naphthalene* & $81(2)$ & $77(2)$ & 19 & 75 & 99 \\
\hline 1,6-dimethyl naphthalene* & $44(2)$ & $63(B D)$ & $\mathrm{BD}$ & 45 & 75 \\
\hline Acenaphthylene & $14(B D)$ & $3(B D)$ & $\mathrm{BD}$ & 6 & 2 \\
\hline Acenaphthene & $49(1)$ & $55(1)$ & 9 & 37 & 46 \\
\hline 2,3,5-Trimethyl & $29(1)$ & $36(1)$ & 6 & 48 & 37 \\
\hline naphthalene* & & & & & \\
\hline Fluorene & $36(1)$ & $52(1)$ & 8 & 57 & 47 \\
\hline 1-Methyl-9H-fluorene* & $3(B D)$ & $9(B D)$ & 3 & 5 & 4 \\
\hline Dibenzothiophene* & $12(B D)$ & $10(B D)$ & 1 & 12 & 10 \\
\hline Phenanthrene $^{\#}$ & $299(6)$ & 411 (8) & 14 & 276 & 212 \\
\hline Anthracene $\mathrm{A}^{\#}$ & $23(B D)$ & $13(B D)$ & $\mathrm{BD}$ & 14 & 8 \\
\hline
\end{tabular}




\begin{tabular}{|c|c|c|c|c|c|}
\hline$\overline{\text { Carbazole* }^{*}}$ & $5(B D)$ & $5(B D)$ & $\mathrm{BD}$ & 2 & 1 \\
\hline Fluoranthene $^{\#}$ & $111(7)$ & $179(6)$ & 4 & 61 & 52 \\
\hline Pyrene $^{\#}$ & $59(5)$ & $93(4)$ & 2 & 32 & 27 \\
\hline Retene & $9(1)$ & $10(1)$ & $\mathrm{BD}$ & 18 & 13 \\
\hline Benzo(a)anthracene ${ }^{\#}$ & $6(3)$ & $10(3)$ & $\mathrm{BD}$ & 2 & 2 \\
\hline Chrysene/triphenylene & $15(10)$ & $30(11)$ & $\mathrm{BD}$ & 7 & 8 \\
\hline Benzo[b]fluoranthene ${ }^{\#}$ & $11(11)$ & $22(20)$ & $\mathrm{BD}$ & 4 & 6 \\
\hline Benzo[k[fluoranthene ${ }^{\#}$ & $4(4)$ & $8(7)$ & $\mathrm{BD}$ & 1 & 2 \\
\hline Benzo[a]pyrene & $2(2)$ & $3(3)$ & $\mathrm{BD}$ & 1 & 1 \\
\hline Benzo[e]pyrene**\# & $4(4)$ & $8(8)$ & $\mathrm{BD}$ & 1 & 2 \\
\hline Perylene* & $\mathrm{BD}(B D)$ & $1(1)$ & $\mathrm{BD}$ & $\mathrm{BD}$ & $\mathrm{BD}$ \\
\hline Indeno[1,2,3-cd]pyrene & $2(2)$ & $4(4)$ & $\mathrm{BD}$ & $\mathrm{BD}$ & 1 \\
\hline Dibenzo[a,h]anthracene & $1(1)$ & $1(1)$ & $\mathrm{BD}$ & $\mathrm{BD}$ & $\mathrm{BD}$ \\
\hline Benzo[g,h,i]perylene & $3(3)$ & $5(5)$ & $\mathrm{BD}$ & 1 & 1 \\
\hline
\end{tabular}

* Estimated concentrations based on calibrations of similar compounds

${ }^{o}$ Possible breakthrough of the species through the system

$\mathrm{BD}=$ Below Detection

$\mathrm{NR}=$ Not Reported 


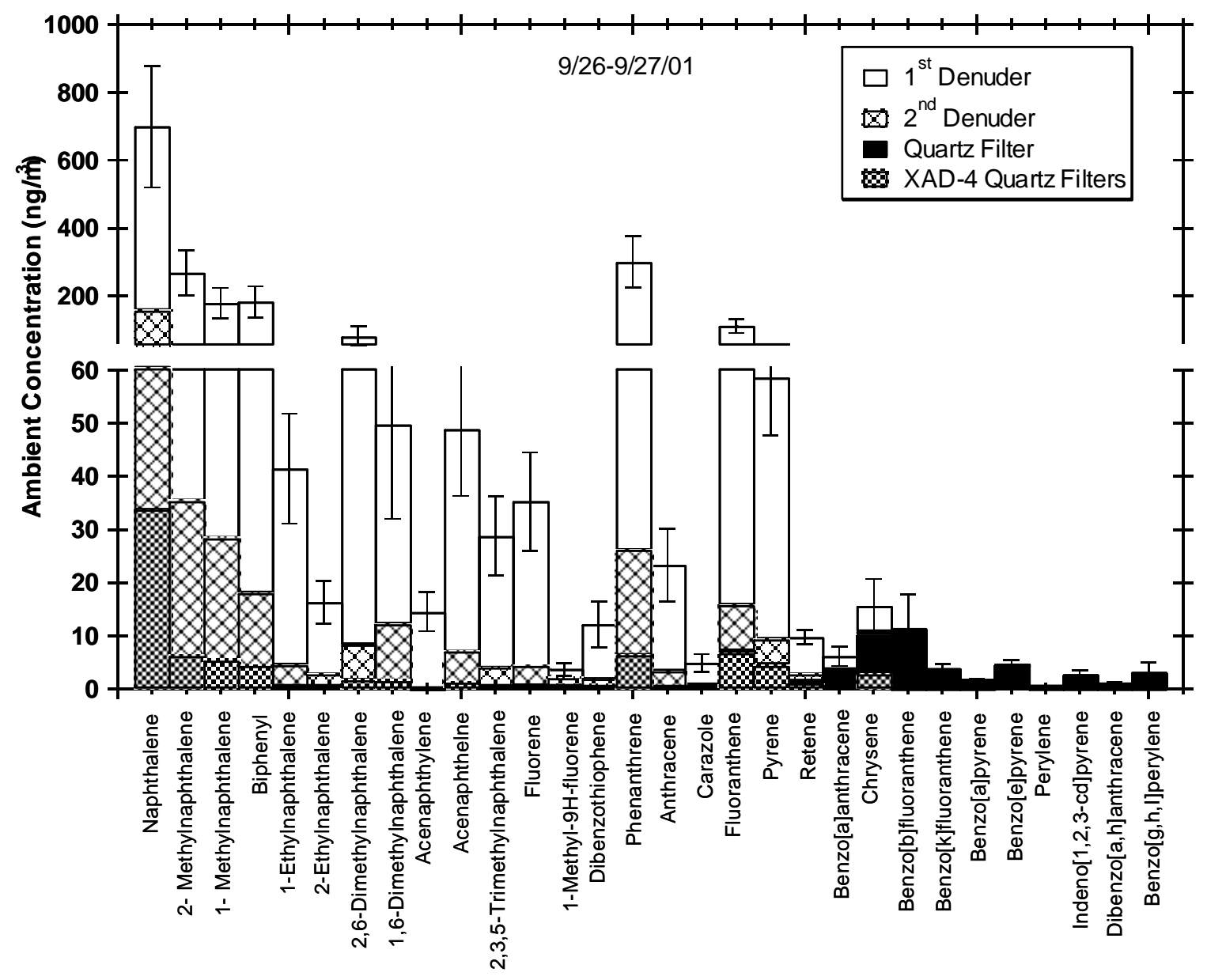

Figure 8. Average concentration of polycyclic aromatic hydrocarbons sampled at lower Manhattan, September 26 and 27, 2001. Generally, molecular weight increases from left to right. Note broken bar between 60 and $200 \mathrm{ng} \mathrm{m}^{-3}$ concentrations. 


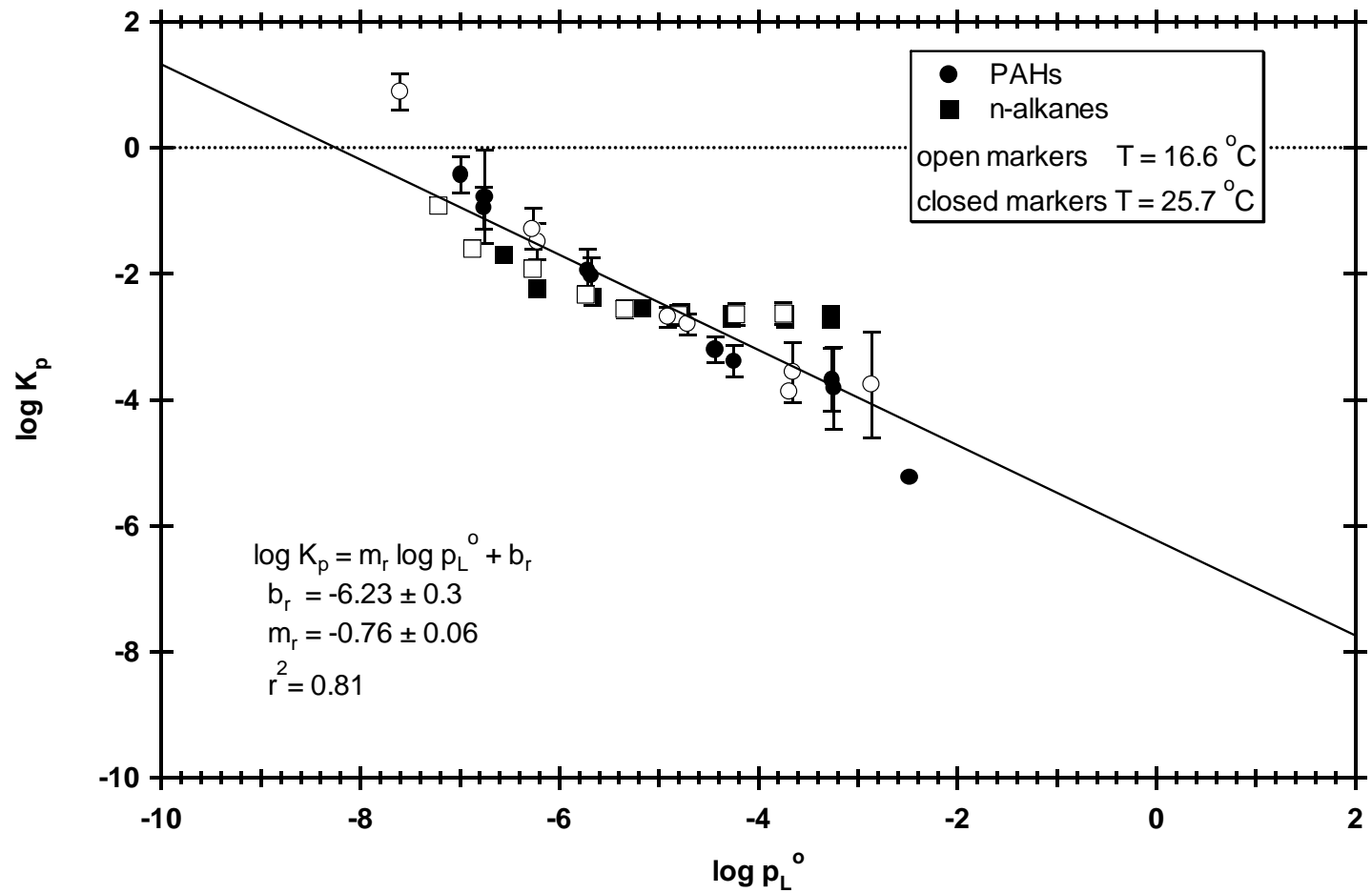

Figure 9. Relationship of gas-particle partitioning coefficient $\left(K_{p}\right)$ as a function of super-cooled liquid vapor pressure $\left(\mathrm{p}_{\mathrm{L}}\right)$ for semivolatile organic compounds collected in the troposphere downwind from the World Trade Center fire. Note: The $\mathrm{K}_{\mathrm{p}}$ values have been corrected for denuder breakthrough. 


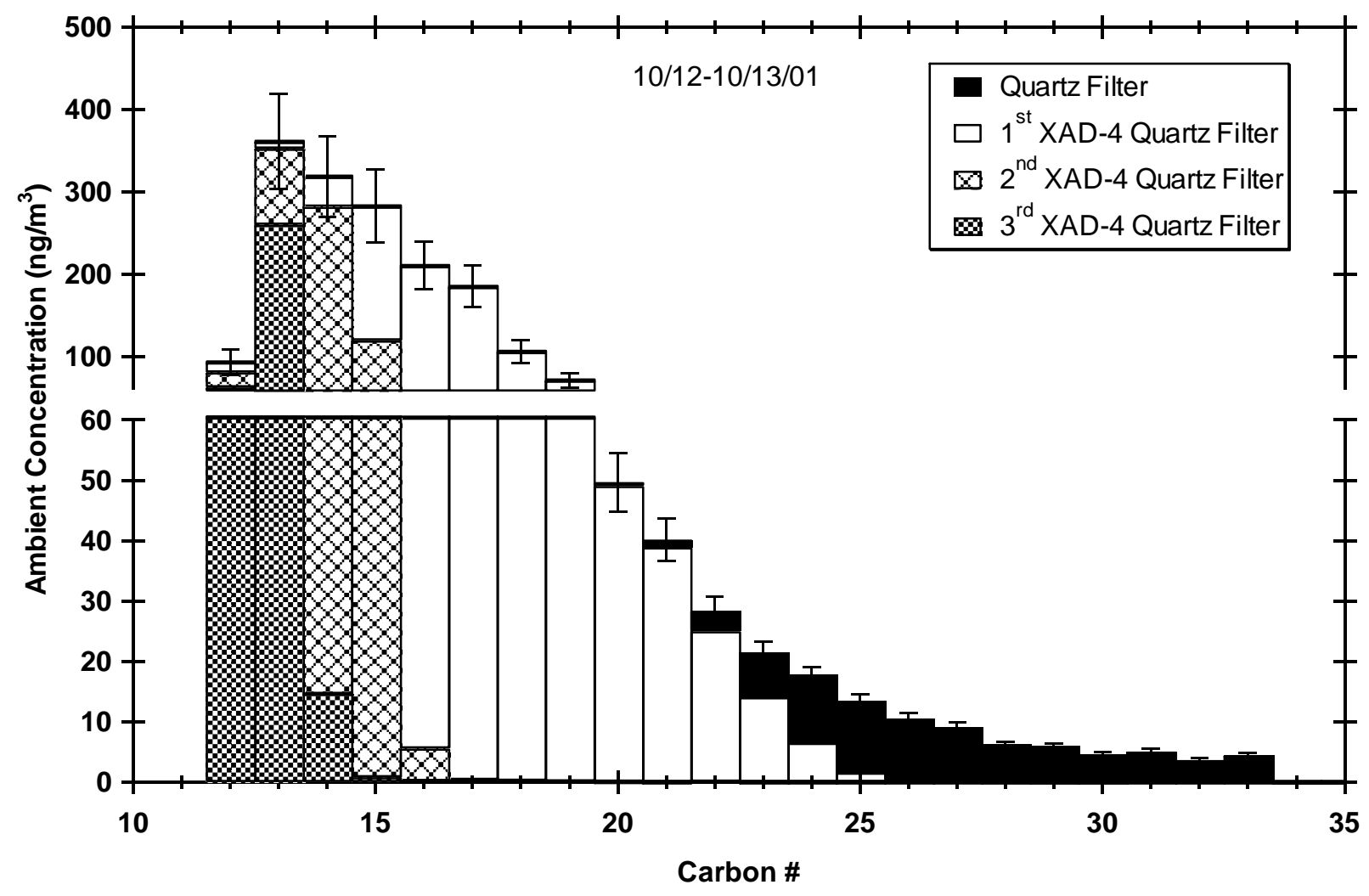

Figure 10. Concentrations of $\boldsymbol{n}$-alkanes in the plume downwind from the World Trade Center, indicating phase distribution. The quartz filter without sorbant material indicates exclusive particle matter. Third XAD-4 impregnated filter, due to breakthrough, indicates almost exclusively gas phase matter. Note broken bar between 60 and $200 \mathrm{ng} \mathrm{m}^{-3}$ concentrations. 


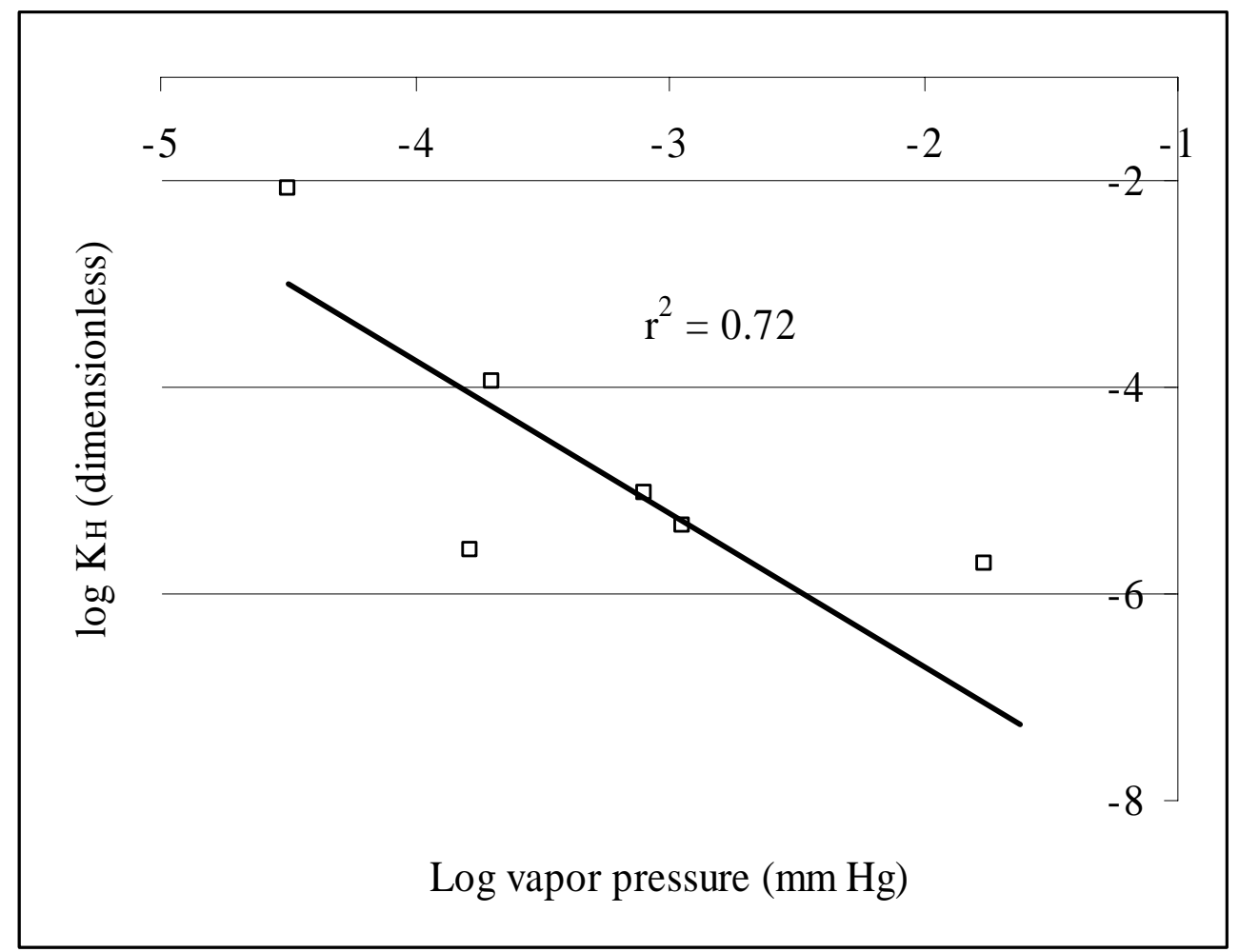

Figure 11. Relationship of measured gas-particle partitioning coefficients $\left(K_{p}\right)$ to published vapor pressures for seven polycyclic aromatic hydrocarbons found in the troposphere downwind from the World Trade Center fire. 


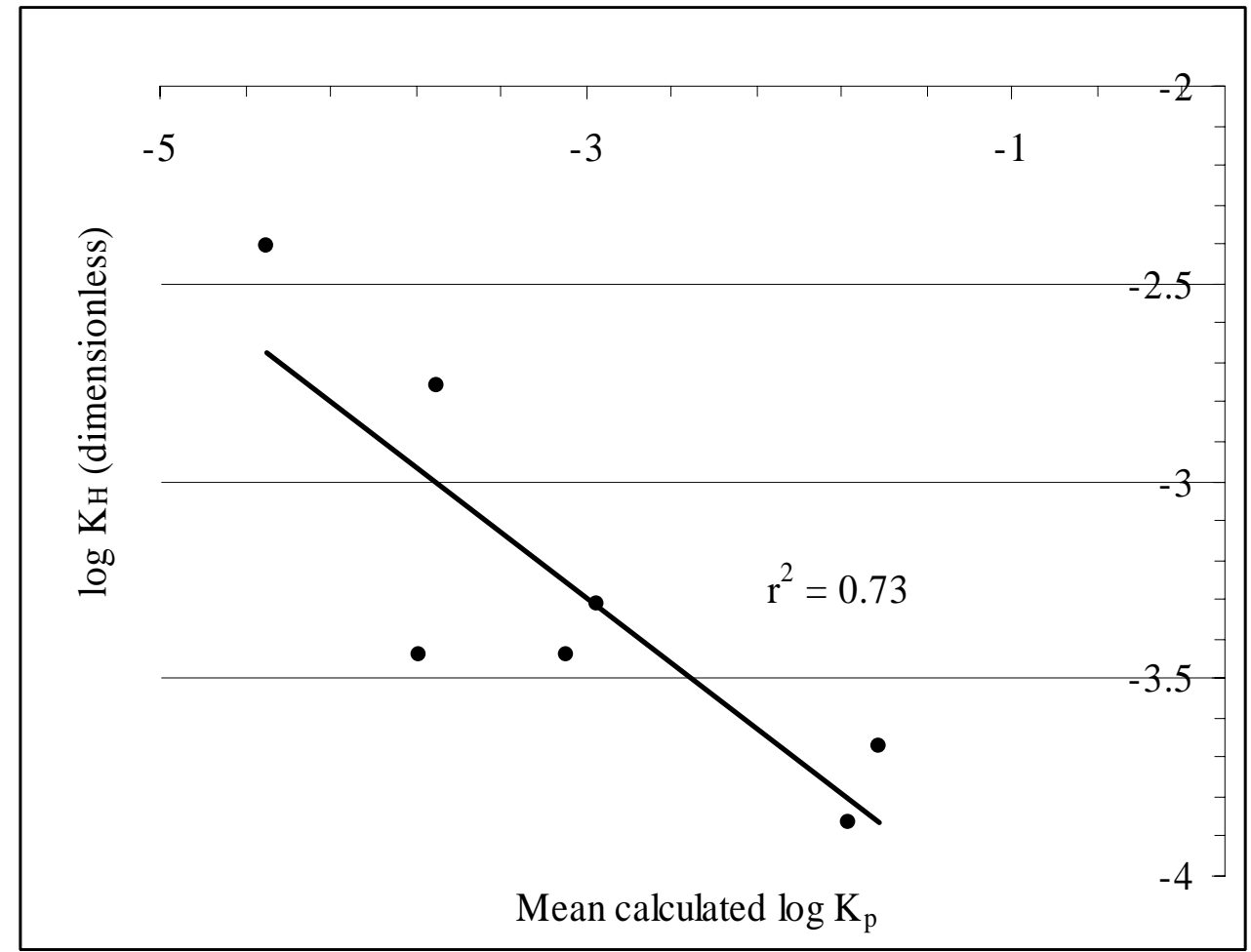

Figure 12. Relationship of gas-particle partitioning coefficients $\left(K_{p}\right)$ to published dimensionless Henry's Law constants for seven polycyclic aromatic hydrocarbons found in the troposphere downwind from the World Trade Center fire. 